\title{
Europe's Zombie Megabanks and the Differential Regulatory Arrangements that Keep Them In Play Edward Kane ${ }^{*+}$
}

Working Paper No. 64

September 15, 2017

\begin{abstract}
This paper analyzes the link between Kamakura Risk Information Services (KRIS) data on megabank default probabilities and credit spreads. It develops an "eye-ball" test for the extent of individual-bank "zombieness" whose grade turns on how weakly a bank's credit spread responds to movements in KRIS default probabilities calculated over different horizons. The intuition underlying the test is that the more decapitalized a bank is allowed to become, the more creditors must be relying on someone other than stockholders to absorb the firm's risk of default. The tests show that the recovery of European megabanks from the 2008-09 crisis has been incomplete. Creditors of Europe's giant banks still seem to be relying on implicit guarantees. In particular, credit spreads on the bonds of these banks appear to be relatively insensitive to the level of the issuer's longer-term probabilities of default. Coupled with the high pairwise correlation that KRIS default probabilities show between major US and European banks, this finding suggests that creditors do not expect the EU's bail-in requirements to play much of a role in resolving megabank insolvencies during the next crisis.
\end{abstract}

\footnotetext{
* Professor of Finance at Boston College and NBER research associate.

+ We thank: (1) the Institute for New Economic Thinking for financial support, (2) Donald van Deventer for generously granting me access to the KRIS database that is central to this research, and (3) Robert Dickler (especially), Thomas Ferguson, Stephen Buser, George von Furstenburg, and Larry Wall for valuable criticism of earlier versions of this paper.
} 
Keywords: Too big to fail, Financial regulation, Financial crisis, Regulatory culture, Financial stability, European banking crisis, Zombie banks, Megabank insolvency

JEL: A14, E58, G15, G20, G38, F02, F34 
Most contemporary economic research squeezes a block of data through a statistical model and goes on to weave numerical estimates of the model's coefficients into a qualitative narrative of what it all means. But in some categories of policy research, the narrative becomes both the alpha and the omega of the inferential process.

For example, US and European central bankers have been determined to portray the Great Financial Crisis as a failure of interbank funding markets and to take credit in the press both for having cured this breakdown by providing massive amounts of liquidity assistance and for erasing the possibility of future megabank bailouts by installing forward-looking programs of structural reform (Yellen, 2017; Adrian and Narain, 2017; Jones, 2017).

Figure 1 shows that a large portion of the cross-border assistance that European banks received came from the US Federal Reserve System. This paper argues that the Fed's so-called "liquidity assistance" can be more accurately described not as a series of successful loans, but as a series of poorly structured equity investments. This is because, whenever the value of a banking firm's stockholder-contributed equity plunges toward zero, credible outside guarantees turn into loss-absorbing equity positions (Kane, 2016a). The paper argues further that the precedent set by the overwhelming size of the crisis-induced cross-border assistance the Fed supplied during the GFC has repurposed the US Federal Reserve System as the world's megabank guarantor of last resort. Finally, the paper hypothesizes that, by using Fed assistance to fund poorly performing and underwater assets at zombie megabanks without doing much of anything to cure their insolvencies, national authorities in Europe are proceeding along the first few ruts in the socially destructive path that industry-captured US officials blazed in the 1980s Savings and Loan (S\&L) mess (Kane, 1989) and that Japanese authorities followed in dealing with their long-lasting banking crisis in the '90s (Kane, 2003). In the long run, these policies reduced the significance of the industries whose member firms they were intended to help.

The paper is organized as follows. Section I defines zombie banks and explains how the explicit and implicit government guarantees they enjoy become part of a zombie's equity funding structure. Section II develops a model-based "eye-ball test" that can be used to indicate when -instead of stockholders - outside guarantors seem to be carrying the bulk of the default risk that a bank's balance sheet ordinarily passes through to its creditors. Section III applies this test to illustrate the temporary zombieness of two US mega-institutions during the 2008-2009 crisis. Section IV uses the same framework to show that, while US megabanks have become 
solvent enough to be trading now more or less on their own credit, a number of European megabanks have not. Section V introduces evidence showing that the stand-alone default probabilities of megabanks around the world are so highly correlated that bail-in protocols that promise to take taxpayers completely off the hook for megabank crises are not credible. Section VI shows that these protocols were extensively circumvented in two recent European crises. Section VII concludes the paper by explaining how it might make sense to focus prudential supervision less on strengthening corporate balance sheets and more on modifying the risktaking incentives of individual bankers.

\section{Zombie Banks and the Zombieness They Spread}

In George Romero movies and in Living Dead TV programs, a zombie is a corpse that, because its rotting body has been reanimated by a plague of some kind, is able to keep moving. Far from lying still, these undead creatures wander around singly or in herds seeking opportunities to feed on the flesh of ordinary humans. Once a zombie bites into a living person's flesh, that person soon becomes a zombie, too.

A zombie bank is a financial enterprise whose stockholder-contributed net worth is deeply negative (i.e., it is so economically insolvent that it faces the likely prospect of a fatal creditor run), but can continue to roll over and even expand its debts because the repayment of these debts is believed to be supported explicitly and/or implicitly by a plague of credible government guarantees.

The credibility of a particular government's guarantees depends on what one may call its perceived capacity to pass the carrying costs of the guarantees to taxpayers. If and when a government's ability to support its guarantees loses credibility (as in Cyprus in 2012), creditors and counterparties of every kind seek to withdraw (or at least to collateralize) the funding they have been providing in hopes of minimizing the loss they might suffer if and when the institution's economic insolvency is finally resolved.

Kane (1989) shows that the deeper a zombie bank's insolvency becomes, the more socially irresponsible its managers' incentives become. Because the small margins associated with the prudent positive present-value loans needed to promote and sustain macroeconomic health offer little chance of returning their firm to economic solvency, the managers are attracted instead to negative present-value deals that -like Hail-Mary passes in American football-- offer 
at least a small chance of a very large payoff. Zombie-bank efforts to raise funds for solvencyrestoring gambles for resurrection spread zombieness by bidding up the interest rates that healthy competing institutions have to pay on their liabilities to levels in excess of the yields that can be earned on prudent loans and investments.

The resulting reallocation of funding harms the real economy in two ways. First, it denies credit to numerous solid positive present-value projects that the zombies' healthy competitors would otherwise have been able to finance. Second, sustaining a horde of zombies created a need to hold back government resources that could have gone into a Keynesian fiscal stimulus program to assure its ability to make good on its implicit guarantees if creditors were to initiate a run on the system.

Accounting for Zombieness. Although implicit and explicit government guarantees can keep a zombie in play indefinitely, the balance sheets that zombies publish fail to show how guarantees accomplish this. Figure 2 shows a publishable accounting balance sheet for a hypothetical $\$ 500$ billion European zombie bank. Its net worth appears to be a positive $\$ 40$ billion because its managers have used various accounting loopholes or outright mis-statements to hide $\$ 100$ billion in losses and outside auditors and government examiners have either not discovered or been ordered not to challenge the methods the firm has used to bury evidence of its actual or impending losses.

On the other hand, by construction, the firm's full-information economic balance sheet has a $\$ 60$ billion hole in it. Because we are dealing with a zombie, we know that one or more government guarantors must be on the hook for this shortfall. Moreover, as long as the zombie's insolvency remains unresolved, stockholders' positions are worth something, because stockholders have a realizable lottery-like claim against the bank's long-shot loans and investments. These claims may return the bank to solvency if enough of these endgame gambles actually pay off.

Far from feeling a duty to protect taxpayers, in some jurisdictions, managers of zombie banks may feel that corporate law requires them to formulate business plans that exploit taxpayers further by steadily maximizing stockholders' increasingly slim chances of the bank's returning to solvency on its own. Figure 3 assumes that stockholders' residual claim is worth $\$ 1$ billion, so that taxpayers' equity position in this firm is worth $-\$ 61$ billion. Assuming the 
zombie's managers continue to act in the interest of their stockholders, the odds are that taxpayers' position will deteriorate further and further, the longer the megabank is allowed to operate in a zombie condition.

The Economics of Guaranteeing Zombies. While correct as far as it goes, the balance sheet in Figure 3 fails to clarify that the value of a rational guarantee contract actually has two distinct pieces: (1) a put option that benefits creditors by allowing losses in excess of stockholder net worth to be assigned to the guarantor, and (2) a stop-loss call option that allows the guarantor to take over the assets of the guaranteed party if and when threshold for transferring losses to the guarantor begins to be approached. For the hypothetical zombie bank depicted in Table 3, exercising the stop-loss call option would transfer $\$ 1$ billion from stockholders to taxpayers.

A megabank can only become deeply insolvent if the guarantor fails to exercise its call on the firm's franchise in timely fashion. In ordinary times, such forbearance may seem attractive to government officials for at least two reasons. First, the macroeconomic and reputational costs of publicizing and resolving the insolvency of a major bank may seem enormous compared to the likelihood that top regulators can complete their term in office without the public ever understanding that they have been secretly subsidizing one or more insolvent institutions. This may explain why in the US big banks want to preserve the so-called Dodd-Frank orderly-liquidation authority against doctrinaire Republican efforts to abandon it (Newmyer, 2017). Formally known as the orderly liquidation authority, the provision in question enables the FDIC to take control of a failing institution, thereby keeping the resolution process out of the bankruptcy courts. Second, the value of post-government employment opportunities and speaking fees promise to be higher if even a few of the zombie firms miraculously recover or if top regulators manage to pass the problem on to their successor without incident. Of course, a crisis so intensifies the bureaucratic and personal payoffs for forbearance that letting megabank insolvencies run has become the go-to strategy of modern crisis management. Still, the S\&L and Japanese experience should have taught regulators everywhere that it is a mistake to let a horde or zombie institutions survive indefinitely. 


\section{Measuring Zombieness}

The simplest models of the default risk that passes through to a bank's creditors and guarantors begin by assuming risk-neutrality and no transactions costs. Assuming further that the bank's debt contracts carry no other priced features (such as call options or conversion rights), the credit-default spread (CDS) -i.e., the difference in the yield on a particular issue of bank debt over the yield on a matched-maturity Treasury security-- should equal the product of the bank's stand-alone probability of default (PD) and the loss a representative holder would expect to suffer given that the bank actually defaults (LGD). This model is conventionally expressed as:

$$
\mathrm{CDS}=\mathrm{PD} \bullet \mathrm{LGD},
$$

where PD and LGD are treated as exogenous variables. Taking logs of both sides transforms (1) into:

$$
\log \mathrm{CDS}=\log \mathrm{PD}+\log \mathrm{LGD} .
$$

Equation (2) tells us that, to a reasonable approximation, changes in unbiased estimates of DP should pass more or less one-for-one into the credit spreads of firms that enjoy no outside guarantees. But because we lack time-series data on LGD, we cannot test this proposition directly. The best we can do is to treat LGD at each date $t$ as if it were a "missing variable" in the following variable-coefficient bivariate regression model:

$$
\log \mathrm{CDS}_{\mathrm{t}}=\mathrm{a}_{\mathrm{t}}+\mathrm{b}_{\mathrm{t}} \log \mathrm{PD}_{\mathrm{t}}+\mathrm{u}_{\mathrm{t}}\left(\mathrm{t}=1,2, \ldots \mathrm{T}_{\mathrm{k}}\right) .
$$

Estimates of $a_{t}$ capture the mean contributions of $\log$ LGD and other omitted variables over an arbitrary sample period of length $T_{k}$, and $u_{t}$ is an error term.

Fortunately for our purposes, movements in log LGD are very likely to be positively correlated with movements in log PD. This means that, in sample periods during which bank creditors are not looking heavily to outside guarantors for support, the estimated slope coefficient $b_{t}$ would be biased upward. This implies that observed movements in a strongly capitalized megabank's credit spread ought to respond sharply to movements in its PD. On the other hand, the deeper a bank falls into distress, the more completely a megabank's creditors begin to rely for repayment on the cross-country safety net of potential third-party guarantors rather than on the earning power of the firm's assets. The stronger and more-credible this reliance, the less surges in a zombie's PD can influence credit spreads on its debt. PDs observed for at least some horizons would run well above the bond spreads observed on at least some of the debt zombie 
banks issue. This is because once a bank is perceived to be operating in a zombie condition, all or most of any increase in its default risk is expected to be shouldered -at least temporarily-- by national and cross-border guarantors.

The KRIS Data Set. The Kamakura Risk Information Services (KRIS) models and publishes daily estimates of PD (called KDP for Kamakura Default Probability) over several different horizons and reports a CDS for all corporate bonds trading publicly in the US. For the full sample of foreign and domestic public firms that meet this condition during the 10 years running from August 2007 to August 14, 2017, Figure 4 tracks the behavior of issuers' cumulative expected default rate over forecast horizons as short as one year and as long as ten years. The heading above the graph displays the expected default rates and the expected number of defaults for all issuers at each horizon as of 8-14-17. The graph itself shows that, at the height of the 2008 crisis, almost 5 percent of issuers were in danger of defaulting within the year and almost 20 percent of the firms were seen as likely to default by the end of the decade. Except for the 7year KDP, as the crisis receded, KDPs shrank steadily through the summer of 2012. Since then, however, long-horizon KDPs (which track the likelihood of distant distress) have been rising markedly.

The model of default probability used to generate the probabilities is the Kamakura Risk Information Services version 6.0 Jarrow-Chava reduced-form default-probability model (abbreviated on the KRIS site as KDP-jc6). The model uses a sophisticated combination of financial ratios, stock price history, and macro-economic factors.

The version 6.0 model was estimated over the period from 1990 to 2014, and thus includes insights conveyed by the Great Financial Crisis. Kamakura default probabilities are based on 2.2 million observations and more than 2,700 defaults. A term structure of default over different horizons is constructed by using a related series of econometric relationships estimated on this database. KRIS covers 38,000 firms in 68 countries, with the data updated daily.

Sections III and IV of the paper track the behavior of KDP and CDS at a few individual megabanks. Our goal is to infer when (if ever) $b_{t}$ is closer to zero than to one. Model (3) implies that the less fully a bank's credit spread responds to surges in its KDP at any time, the more confidently the bank's creditors are relying for repayment on governmental safety-net guarantees. 


\section{Measuring the Extent of a Firm's Zombieness}

The principal beneficiaries of a bailout are a firm's creditors. In setting out equation (3), we explained that how a distressed firm's credit spread responds to surges in its KDP should depend on how fully its creditors feel they need to rely for repayment on one or more elements of the global financial safety net. The next few figures use graphs to illustrate credit-spread behavior in and out of crisis: for GE (as a baseline) and for a few representative US and European megabanks.

To make sense of these graphs, readers have to understand KRIS's system of coding the information that it graphs:

- Blue dots plot the credit spread, based on actual trades and calculated using matched-maturity Treasury. This is different from the convention that uses the nearest shorter US Treasury on-the-run yield.

- Light Blue lines show the volume of trading in the selected bond.

- Orange lines: 1 year Kamakura Risk Information Services reduced-form default probability (KDP), version 6.0.

- Green lines: 10 year KDP (unless otherwise noted) KRIS reduced-form defaultprobability, version 6.0.

Because finance is only a small part of GE operations, the credit spread (the blue dots) on the GE bond illustrated moves sharply with surges in its 1-year KDP (orange line) and stays high even after its 1-year KDP bottoms out. Its credit spread recedes slowly, presumably as its business problems lessen over the post-crisis era. As the bond nears maturity, surges in the 5-year KDP become less and less relevant.

Figures 6 and 7 plot the same information for two US megabanks that were purported to be especially weak at the outset of the GFC. The graphs show that implicit and explicit safetynet protection dampened the response of these megabank's credit spreads to surges in the bank's one-year and 10-year probabilities of default. The extent to which 2008-2012 spreads did respond suggests that bondholders were far less than perfectly confident that safety-net support would be complete. However, when KDPs surged briefly in 2016, both bonds had become very short and confidence that the net would protect the bondholders appears almost absolute. 
Though not shown here, spreads for other giant US banks, including JPMorgan Chase and Wells Fargo, showed the same pattern. Figure 8 tracks the credit spread and default probabilities for what was a 9-year Lehman Brothers bond in 2008 during that firm's final nine months of operation. In mid-2008, Lehman's one-year KDP began to surge, but because the firm was believed to be TBTF, its credit spread did not begin to move until the firm's last few days. The credit spread moved up rapidly in the few trades that managed to get executed as its debt price crashed. ${ }^{1}$

\section{Proliferation of Zombie Megabanks in Europe}

Treating the behavior of spreads and default probabilities for US megabanks in the 20082009 crisis as a benchmark, this section presents evidence that European megabanks were also thought to be TBTF during the Great Financial Crisis. Much as we saw for Bank of America and Citigroup, the largest banks in Europe experienced surges in KDP that would have burst through any graph of their blue-dotted credit spreads. Some failed, others merely limped along in the aftermath and, during the last few years, appear to be becoming dangerously fragile again. Although they use formal models and different data, Gehrig and Iannino (2017) also find that the largest European banks remain dangerously fragile.

Figures 9 and 10 show surges in KDP at Deutsche, and Figures 11 through 14 provide similar data for Credit Suisse and Lloyds during both crisis and recent years. Because neither CS nor Lloyds had any bonds trading in the US until the crisis began to recede, KRIS could not record their credit spreads during the GFC, subsequent surges in their orange one-year KDP line through the blue-dotted credit spreads indicate that they and UBS have experienced a touch of zombieness in recent years.

Deutsche Bank is a particularly interesting case. It became a zombie during the GFC and the KDPs and default swap spreads posted in Tables 1 and 2 suggest it is a zombie now. Figure 9 shows that in mid-2008, even before the GFC began, the bank's one-year KDP surged through the credit spread on its frequently-traded 9-year bond and surged again even more strongly in 2009.

\footnotetext{
${ }^{1}$ In section VI, we observe the same pattern of surprise and rapid deterioration in prices for Banco Popular securities in June, 2017.
} 
Figure 10 omits the crisis years to focus on how the bank's KDP and the spread on this same bond behaved in September and October, 2016. The steep climb of the blue dots to the orange line on this then very-short bond on the $14^{\text {th }}$ of October shows that creditors were temporarily unsure whether Deutsche could survive the pressure created by the US Department of Justice's proposed $\$ 14$ billion fine. The size of the fine -which was for misrepresenting the risks in mortgage-backed securities that it sold in the years leading up to the crisis-- far exceeded DBK's accounting net worth at the time. But, as with European megabanks in 2008-2009, the US helped the bank (by reducing the fine to $\$ 7.2$ billion and greatly easing its terms), and the other parties trapped in this particular game of Chicken --the German and EU governments-convinced DBK's principal stockholders to permit the bank to dilute their positions by issuing more stock.

But the KDPs and credit default swap spreads displayed in Tables 1 and 2, respectively, indicate that Deutsche may still be the most-worrisome zombie bank in the developed world. The tables also indicate that two Spanish megabanks --Banco Santander and BBVA-face an only slightly less-perilous long-run future. Figures 15 and 16 show that both banks were zombies for much of 2016. While their one-year KDPs have since receded, their 10-year KDPs remain high relative to the credit spread on the 8-year bond examined here. Figures 17 and 18 show that HSBC and Paribas, suffer to differing degrees from the same issues: (1) evidence of zombieness in 2016 and (2) their 10-year KDPs are still not being adequately priced.

Bond markets' consistent failure to price the longer-run credit risk in securities issued by these and other European megabanks is a form of Pigouvian market failure in which the social cost of bonds that megabanks issue exceeds their private cost. At the same time, it is an indication of these same markets' informational efficiency, in that they are pricing the continued likelihood that, for the world's megabanks, the deferential norms of financial regulation will sufficiently over-ride the EU's bail-in requirements to keep LGD in any actual resolution very close to zero. These graphs indicate to me that, despite worldwide efforts to strengthen bank capital positions and EU efforts to force bail-in, bondholders remain confident that they will be rescued if another crisis hits within the decade. The next section argues that EU regulators' tough talk about bail-ins softens in practice because it is not yet backed up by the supervisory culture, skillsets, and tax-collecting capacity needed to recapitalize the region's zombie megabanks. 


\section{How Megabankers Dictate Resolution Policy}

The first level of the global safety net supporting European megabanks consists of nationbased deposit insurance, central-bank lending, and supervisory forbearance. Using yearend 2008 data, Demirgüç-Kunt and Huisinga (2010) identified 30 publicly listed banks worldwide whose liabilities exceeded half of their country's GDP. To relieve doubts about such countries' ability to rescue their largest banks, a second and regional level of defense came into being. It consists of emergency funding that EU governments, the EU, or the ECB can make available to aid distressed banks and/or their governments. Backup financing by the International Monetary Fund serves as a third and international level of support. The fourth and final level consists of the hegemonic Federal Reserve's strong commitment to preventing the world's financial system from breaking down. The Fed's demonstrated propensity for rescuing foreign banks means that US taxpayers serve de facto as the world's guarantors of last resort.

Around the world, megabankers have learned that in and out of crises the pressure they can exert politically on this support network conveys to them an ability to hold the world's macroeconomy hostage to extract subsidies from taxpayers. Megabank cultures support this ability by claiming the right to overstate a bank's strength to forestall customer runs and hiding behind this cover to pursue profit-making opportunities that aggressively risk the solvency of their firm so that stock markets can shift substantial amounts of tail risk through the safety net to unwary taxpayer guarantors.

Given the Fed's post-crisis support for European zombies and their governments (signaled through currency swaps and, perhaps less deliberately, through interest paid on foreign-bank deposits by the $\mathrm{Fed}^{2}$ ), individual-country regulators can afford both to give insolvent megabanks an undeserved benefit of the doubt and to expand their national safety nets to give their particular zombies additional credit support (Demirgüç-Kunt, Laeven, and Kane, 2015). Instead of trying to benchmark and resolve megabank zombies, signaling the existence of implicit safety-net guarantees and minimizing creditor haircuts at banks that have to be resolved seems - for both political and career reasons - the safer path to follow.

\footnotetext{
${ }^{2}$ Burne (2015) reports that in 2015 almost half of the $\$ 6.25$ billion that the Fed paid in interest on reserves went to units of foreign banks. However, Wall (2015) maintains that decisions about the interest rate paid on bank reserves trace primarily to domestic considerations.
} 
The root problem is that, no matter how much supervisory and resolution authority expands, the unspoken cultural norms (les non-dits) that govern the exercise of this authority remain much the same. Kane (2016) identifies these norms as:

1. A central-bank commitment to protecting and expanding agency and clientele turf

2. Industry-centered norms of client service, protection, and partial acceptance of blame when crises occur.

3. Loss-concealment norms (e.g., efforts to disguise their tolerance for the overvaluation of poorly performing loans at distressed banks);

4. Mercy and benefit-of-the-doubt norms that delay the recognition and resolution of client insolvencies;

5. Norms of individual career management:

a. Blame-avoidance norms (rocking the boat or challenging higher-ups is seen as career suicide);

b. An understanding that is okay to nurture one's post-government employment and speaking opportunities.

These norms lead to what I call the "culture-driven megabank-bailout hypothesis." This model portrays crises as repeated games of chicken whose play is rooted in: (1) the durability of top-manager incentives to pursue tails risks at megabanks; (2) the durability of concealment and deferential benefit-of-the-doubt norms at regulators and central banks; and (3) the high correlation of stand-alone default probabilities across major banks in US and EU. The high correlations illustrated in Table 3 undermine the plausibility of the EU's formal commitment to bailing in creditors at zombie megabanks. They tell us that, when a megabank anywhere is in distress, the others are more apt to need help than to be able to assist a bank's home-country regulator to distribute safety-net loss exposures fairly.

Role of the Revolving Door. Figure 19 shows that the salaries paid to top US officials in the government and private sectors have diverged steadily over the last 70 years. Cross-country competition for executives makes it likely that salaries have evolved similarly in other countries, too. This has increasingly incentivized top government officials to use the "revolving door" between private and government employment to narrow the gap in lifetime income that government service creates by seeking out post-government earnings in the financial sector. 
After leaving public office, senior Fed and Treasury officials have in recent years made considerable use of both sources of post-government rewards allowed by Norm 5b. The next paragraph mentions a few recent cases.

According to the New York Times, Alan Greenspan was hired to consult for the hedge fund Paulson \& Company, Deutsche Bank, and the bond investment firm Pacific Investment Management Company. Former Treasury Secretary Timothy F. Geithner joined the private equity firm Warburg Pincus. Finally, Ben Bernanke is now associated with the Brookings Institution and maintains a busy post-government speaking schedule. Besides a profitable week of enlightening foreign audiences in March 2017, Dr. Bernanke made several other appearances in the Spring, including appearing at a private equity conference hosted by the Blackstone Group. In the fall, he is scheduled to speak at the SALT hedge fund conference in Singapore. Morgan Stanley was reportedly (according to the NYT again) negotiating to have him speak at a dinner on the sidelines of the conference.

At the staff level, the poaching of (say) a top derivatives expert such as Til Schuermann, by Oliver Wyman simultaneously weakens the Fed's supervisory regime, while the expertise he brings with him can help Wyman's clients weave their way through loopholes in the ECB's stress tests, in this case due to deep knowledge acquired in 2014 by leading efforts to construct the Asset Quality Review.

\section{Recent Examples of Culture-Driven Megabank Bailouts}

Although advertised in 2012 as a way to integrate banking and regulatory systems across the Eurozone, the European Banking Union has had the opposite effect. The heart of the problem is that the pattern of integration is incomplete. Its governance structure fragments authority over critical functions of the national and regional safety nets (Giacche, 2017). Member governments have ceded a considerable amount of bank supervisory and closure authority to Brussels, but the deposit-guarantee, insolvency-resolution, and payout authority (though constrained by Brussels bail-in requirements) remains with national central banks and deposit-insurance systems. The disconnection makes it practically impossible to handle runs and insolvencies at individual banks fairly and efficiently.

This section seeks to confirm this claim by examining the treatment of distressed creditors at Banco Popular (BPM) in June, 2017 and comparing its resolution strategy with the 
treatment creditors received at Deutsche Bank in September 2016. I argue first that Banco Popular's closure in June 2017 snuck up on creditors and stockholders and that the last few days of delay in closing its books underscore several serious loopholes in the EU's bail-in rules. I go on to argue that the behavior of Deutsche's KDP and stock price in 2016 supports the hypothesis that regulators believe that it is always far cheaper for them to bail out a world-class megabank than either to nationalize it, liquidate it, or put it into bankruptcy. The suddenness of DBK's stock-price turnaround (shown in Figure 20) strongly suggests that its major creditors received credible back-door assurances of German and US support in October 2016.

Banco Popular. It is helpful to review the Banco Popular resolution first. Banco Popular was the sixth largest bank in Spain and widely thought to be TBTF. Although BPM stockholders, Cocos and some non-senior creditors were wiped out, the BP resolution is, at best, a bungled runinduced bailout accompanied by a highly selective partial bail-in. The key point is that, while stock and bond prices were collapsing, savvy creditors were granted time to exit, collateralize, or swap out their positions as the government burned through almost $\$ 4$ billion in taxpayerfinanced "Emergency Liquidity Assistance" in the bank's last few days. Popular's assets and the positions of depositors and senior creditors were assumed, for a symbolic fee of one euro, by a deliberately regulator-enhanced and monopoly-strengthened zombie, Santander Bank.

The resolution strategy Spain followed in this case has been followed before. It closely resembles how in the 1980s the now-defunct Federal Savings and Loan Insurance Corporation (FSLIC) squandered taxpayer resources by repeatedly merging insolvent S\&Ls into larger zombie institutions to postpone the need to book the full costs of resolving the insolvency of either partner. In FSLIC's deals, strengthening the market's perception of the acquirers' implicit guarantees was understood to be a primary goal.

Kevin Dowd (2015) argues that the true purpose of stress testing individual banks is to give citizens false comfort. Figure 21 shows that giving the bank a phony pass on its Spring, 2017 stress tests supported the price of Banco Popular's contingent convertible bonds for only a few weeks. The credibility of its stress-test results was thrown into question by the release of competing measures of the bank's risk exposure by NYU and the IMF, which showed serious shortages of capital at this and several other EU banks that had received passing grades. 
In any case, Figure 22 shows that creditors and stockholders were slow to understand that the bank's losses might exceed what the EU would allow the Spanish government to absorb. The decision to close the bank suggests that Popular had concealed massive losses for some time in the accounting data that the EU stress tests had used.

The closure decision was formally triggered by the EU's Single Resolution Board (SRB), which declared the bank to be "failing or likely to fail." This declaration started a bail-in process in which shareholders, Coco investors, and perhaps some classes of bondholders would be wiped out and credit-default swaps written on BP would pay out as well. But it also started a parallel process of legal challenges by would-be loss bearers (Hale, 2017). Lawsuits filed by bondholder and shareholder groups seek to invalidate the closure or to win damages on various procedural grounds. Ironically, these suits have held up payouts on credit default swaps because of the need to subtract from the payouts a defensible estimate of the value to be assigned to the possibility that bondholders' might prevail in these suits (Smith, 2017).

Although no explicit injection of taxpayer funds took place that does not means taxpayers got off scot-free. Santander could not have taken on the portfolio of toxic loans that brought Popular to ruin without prior due diligence unless the deal included a substitute for the diligence they did not have time to perform. For the deal to make sense ex ante, Santander had to receive assurances of contingent loss absorption from appropriate officials in the form of tacit guarantees and long-lived options to put a high portion of whatever turn out to be uncollectable assets back to the Spanish government in some way.

The true cost of any rescue is slow to reveal itself. Officials' confidence in the length of this lag is the key to understanding why the world's central bankers think it is cheaper for them to let Deutsche fester indefinitely as a zombie. As we saw with Popular, whenever regulators initiate a bank closure, they face a spate of lawsuits from parties who feel aggrieved by the deal. The potential messiness of having to defend in open court decisions that were made under urgent deadlines imposed by scary creditor runs helps to explain regulators' preference for offering extended forbearances and (when closure can't be avoided) minimal haircuts in the resolution of giant banks.

The Unacknowledged Bailout of Deutsche Bank in 2016. The culture of Deutsche Bank in recent years has been described as more American (i.e., daring) than the Americans and more 
Swiss (i.e., avaricious) than the Swiss. Read properly, this aphorism expresses my claim that megabanking has deteriorated into a protection racket. Megabankers know that many of the risks they take in boom years are reckless, but they take them anyway. When the risks materialize, they demand that taxpayers rescue them or else, usually in nontransparent ways that can be made to reflect well on career-minded regulators when the economy picks up again.

Everyone understands that a firm's stock price will go up if some of its debts receive an underpriced explicit or implicit guarantee. In my opinion, the dramatic reversal of DBK's stockprice decline in September 2016 is hard (if not impossible) to explain without supposing that DBK's major creditors and counterparties received one or more kinds of tacit assurance from one or more governments.

In accepting an outside guarantee, we have seen that a bank enters two contracts:

1. A put option that allows losses beyond its shareholder equity to become the responsibility of the guarantor for DBK unbooked losses.

2. A call option on its assets that allows the guarantor to stop losses and take over the upside of the firm at a specified level of near-insolvency.

Too-Big-to-Fail banks, such as Deutsche, exploit regulators' mercy and client-protection motives to forestall the exercise of the call. When they fall into distress, managers and regulators cooperate in mischaracterizing the bank's problems as merely a shortage of liquidity. Authorities' demonstrated propensity to avoid exercising the call inherent in megabank depositinsurance contracts transfers more and more value into these banks' stock price as their tail risk increases. By definition, too big to fail means that investors are confident that the call will be negated at TBTF banks, so that even when the economy is booming, the aggressive pursuit of tail risk transfers value from taxpayers through the put to stockholders and (through stock-based incentive contracts) to managers of TBTF banks.

It is instructive to compare the behavior of Popular's stock price in April and May of 2017 with the behavior of Deutsche's stock price in September 2016. Information surfaced on September $28^{\text {th }}$ or $29^{\text {th }}$ that not only stopped, but sharply reversed the steep fall DBK's price had been experiencing. On the $28^{\text {th }}$, Westler (2016) reported on an "emergency plan" in which "the state would participate directly in the bank" and Deutsche might be asked to raise $\$ 10$ billion in equity. 
Interestingly, a New York Times article published on the $27^{\text {th }}$ quoted the firm's chief communications officer to the effect that a government bailout was "not on our agenda" and the firm was "determined to meet its challenges on its own." The Times additionally published the following more precise statement, which my bracketed comments and Deutsche's subsequent stock-price surge suggest was a coded message that was at best only half true: "A Deutsche Bank spokesman said on Monday that John Cryan, its chief executive, had "at no point" asked Chancellor Angela Merkel to intervene in the issue with the Justice Department. [N.B. This does not exclude other paths for requesting or receiving bailouts.] The spokesman said that a government bailout was "not on our agenda" [it might be on someone else's agenda though] and added, "Deutsche Bank is determined to meet the challenges [of negotiating a rescue] on its own [i.e., without any explicit intervention by Merkel].” Despite the denial, speculation abounds that Deutsche Bank will once again be forced to ask investors [and perhaps other parties] for more cash [or guarantees] at the moment of extreme weakness."

In the end, the DOJ reduced its fine to $\$ 7.2$ billion and eased the terms under which it would be collected. DBK launched a $\$ 8.6$ billion rights issue that shored up its net worth and diluted existing stockholders, and Donald Trump (one of DBK's major credits according to McLannahan, et al., 2017) was elected President of the US. The half-true statements featured in the passage we just dissected illustrate how easy it is for banks and governments to use slippery denials and nontransparent transfers of loss exposures to forestall creditor runs that threaten the failure of this or any other world-class bank. In this instance, the alleged denial made use of four major tools for distorting information:

- Incomplete framing of issues and actions at stake [acting as if Angela Merkel was the only outside party that could help]

- Diversion [weaving a narrative of half-truths that takes considerable effort to unravel]

- Deflection [putting critics off-balance by employing an anti-bailout rhetoric]

- Floatation of trial balloons [offering multiple lines of half-truths to see which lines best survive critical scrutiny].

\section{Conclusion: The Limited Usefulness of the Postcrisis Reforms Adopted in Europe}

Figure 23 contrasts the high level of the one-year KDP for Deutsche during the last few years with the low level of the median one-year KDP at US banks. Combining this information 
with the insensitivity of credit spreads to 10-year KDP's at this and other European megabanks indicates that the virtual endlessness of opportunities for regulatory arbitrage makes it dangerous for taxpayers to rely entirely on regulation and supervision to control risk taking at megabanks. The renewed downward trend in DBK's stock price shown in Figure 22 reinforces this point. Postcrisis reforms in regulation and supervision may have reduced default risk at smaller US banks, but bondholders are telling us that they expect managers of DBK and other European megabanks to minimize the intended long-run effects of these measures.

Kane (2016b) points out that UK regulators have begun to develop a complementary third category of controls, consisting of a heightened and easier-to-prosecute ladder of penalties for individual bankers who can be shown to be responsible for breaches in regulation that contribute to the failure of their bank. 


\section{FIGURE 1}

GLOBALIZATION OF US NET OCCURRED DE FACTO DURING 2007-10 CRISIS: THE FED USED ITS LAST-RESORT LENDING POWERS CREATIVELY TO PROVIDE SUBSIDIZED FUNDING TO MANY OF THE LARGEST BANKS IN THE WORLD (Fed Loans 8/2007-4/2010)

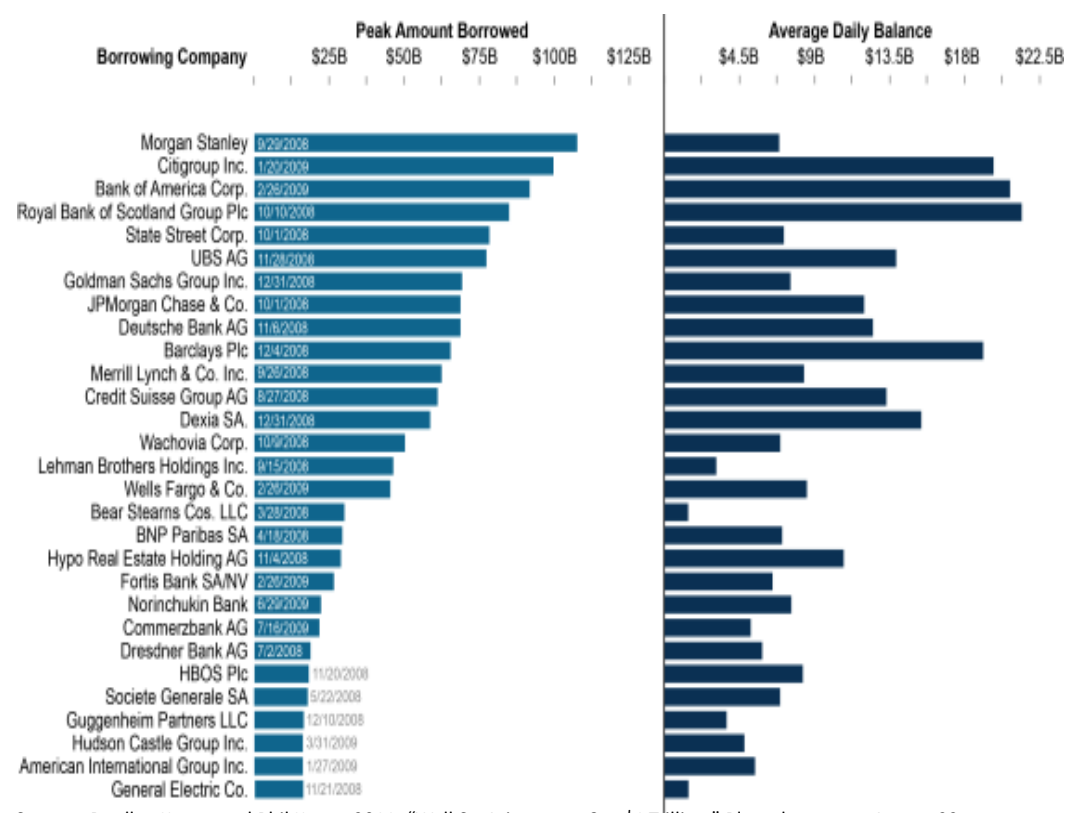

Source: Bradley Keoun and Phil Kuntz, 2011, "Wall St. Aristocracy Got \$1 Trillion," Bloomberg.com, August 22 (transmitted to me by Richard Herring). 
FIGURE 2

A HYPOTHETICAL ACCOUNTING BALANCE SHEET FOR A \$500 BILLION EUROPEAN ZOMBIE MEGABANK

\begin{tabular}{c|c} 
ASSETS & LIABILITIES \\
\hline Assets \$500 billion & Deposits and Other Debt \$460 billion \\
Hidden Losses (\$100 billion) & Stockholder Net Worth \$40 billion
\end{tabular}

FIGURE 3

FULL-INFORMATION ECONOMIC BALANCE SHEET FOR THE SAME HYPOTHETICAL EUROPEAN ZOMBIE MEGABANK DEPICTED IN FIGURE 2

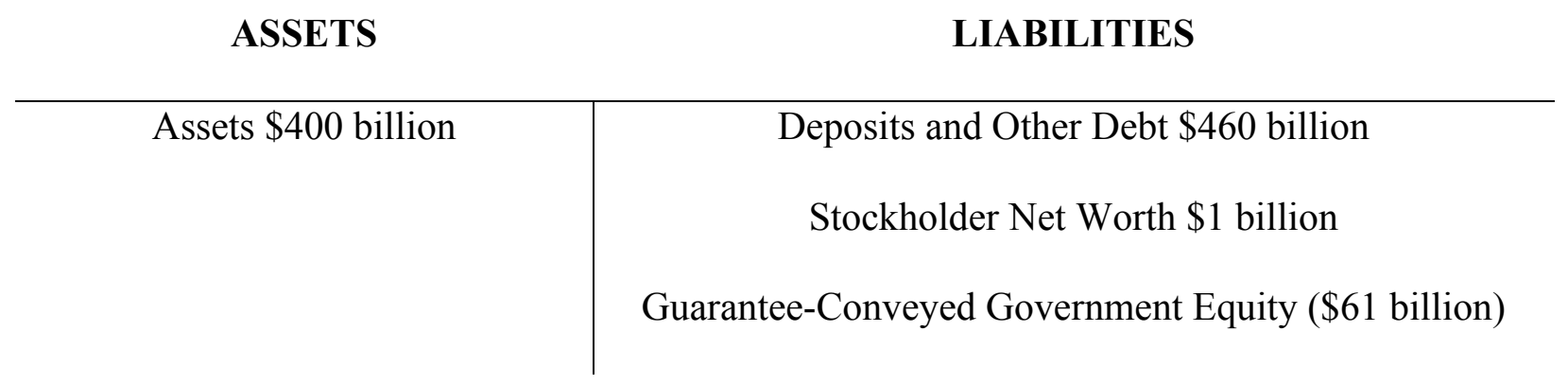


FIGURE 4

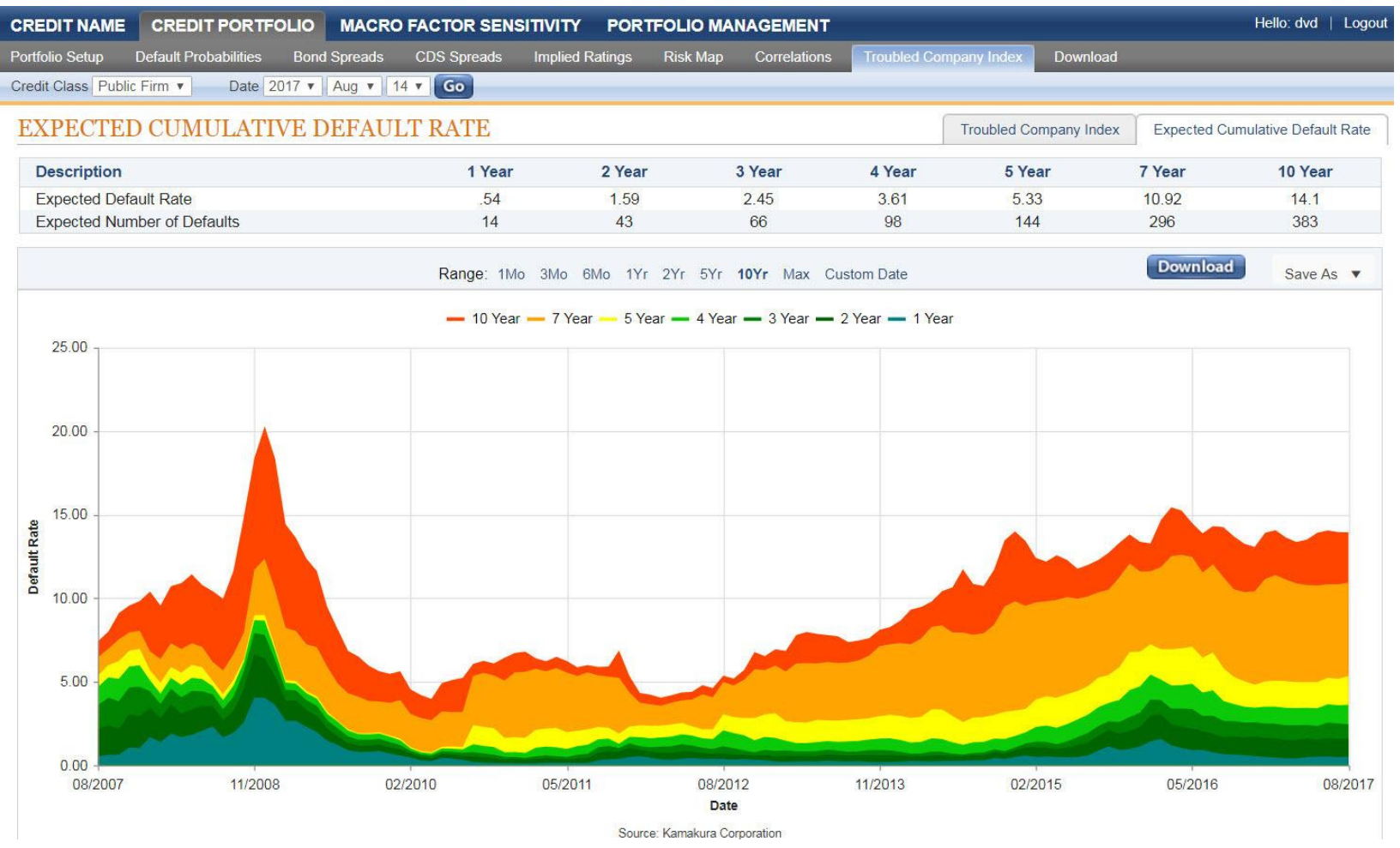


FIGURE 5

BASELINE BEHAVIOR OF CREDIT SPREAD ON A GE BOND MATURING IN JUNE, 2017, REPRESENTING THE DEBT OF A MAJOR FIRM NOT EXPECTED TO BE COVERED BY THE FINANCIAL SAFETY NET

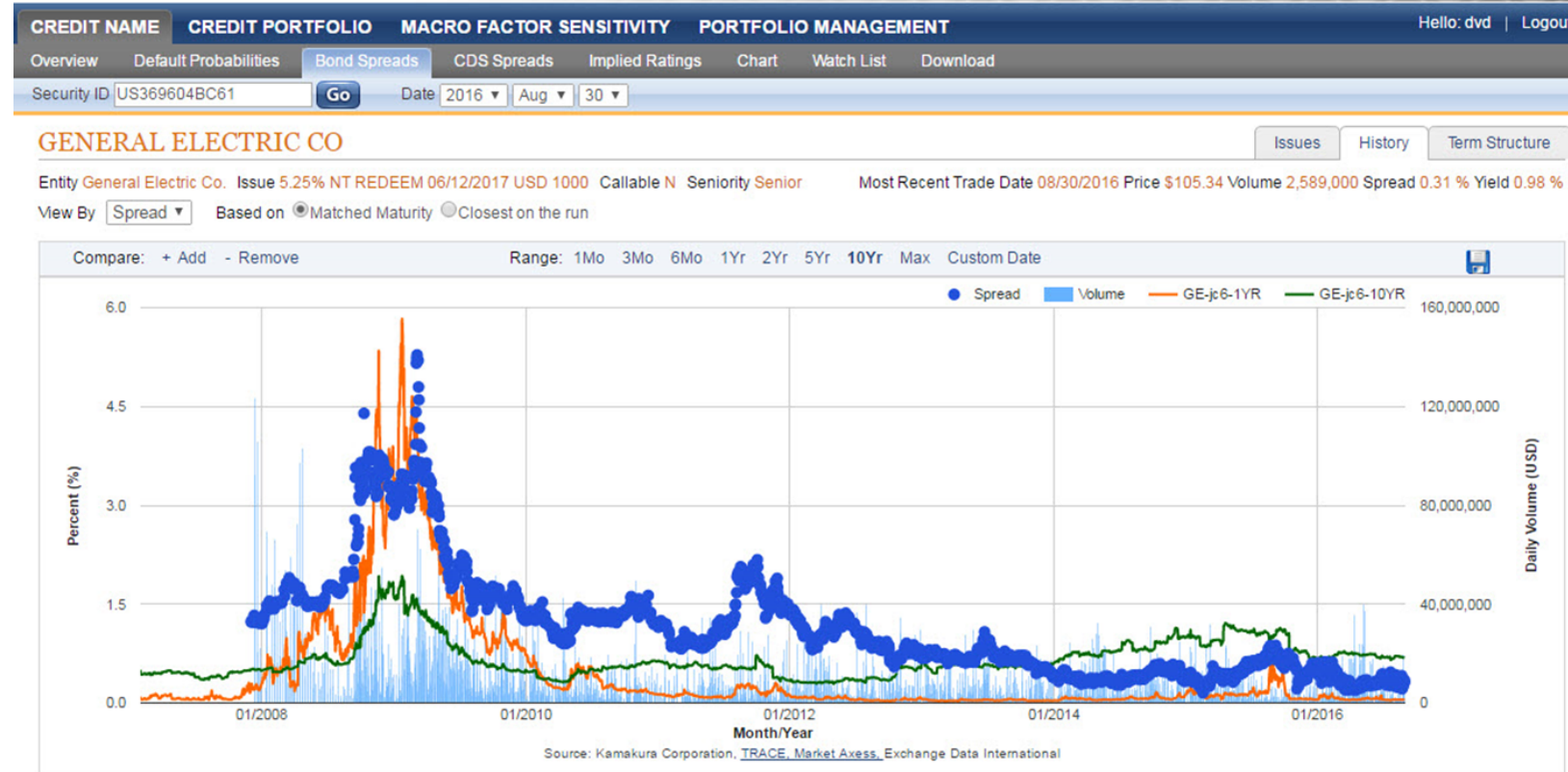




\section{FIGURE 6 \\ 2008-2016 BEHAVIOR OF THE CREDIT SPREAD ON CITIGROUP BOND MATURING IN AUGUST 2017}

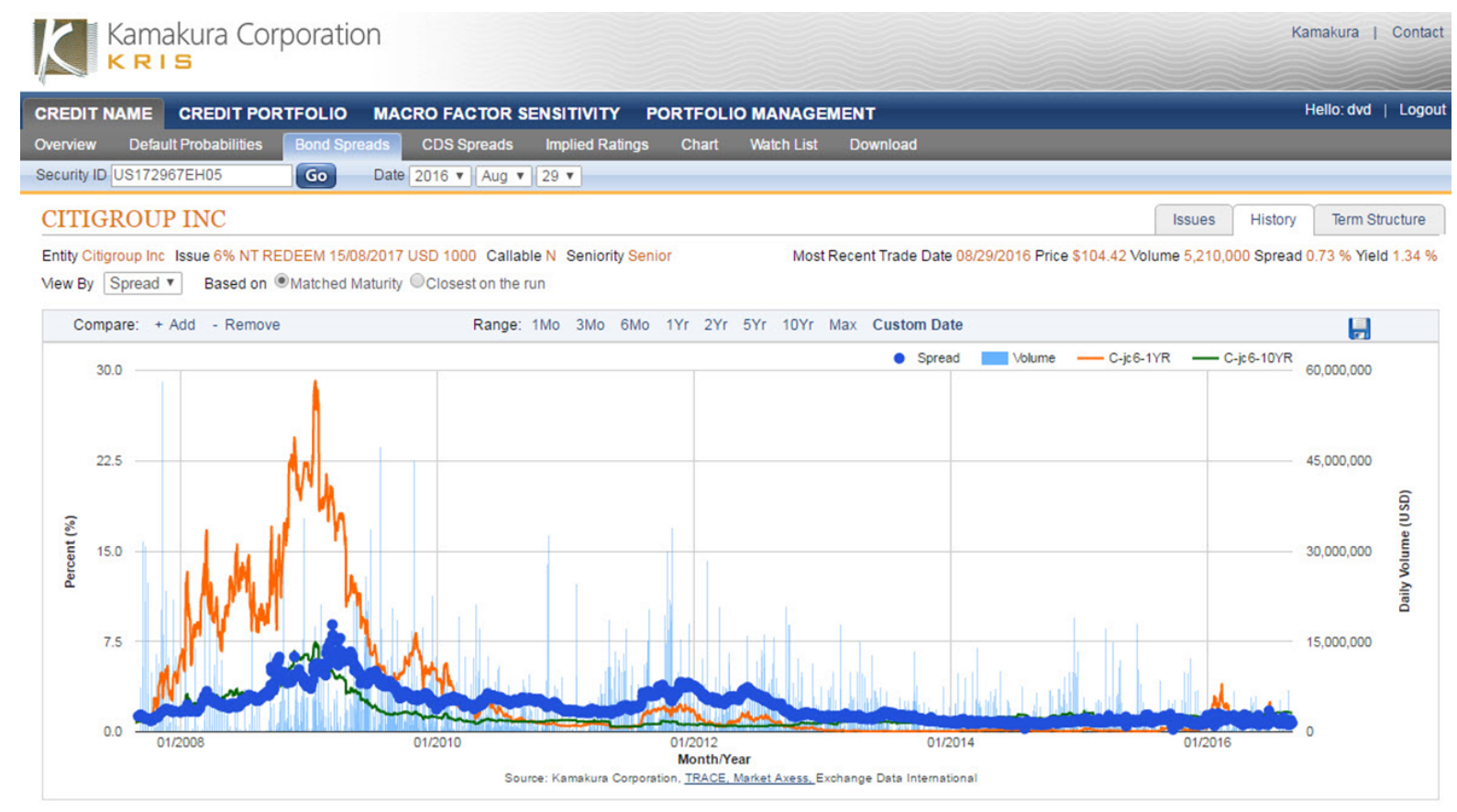

FIGURE 7

2008-2016 BEHAVIOR OF THE CREDIT SPREAD ON A BANK OF AMERICA BOND MATURING ON 12-1-17

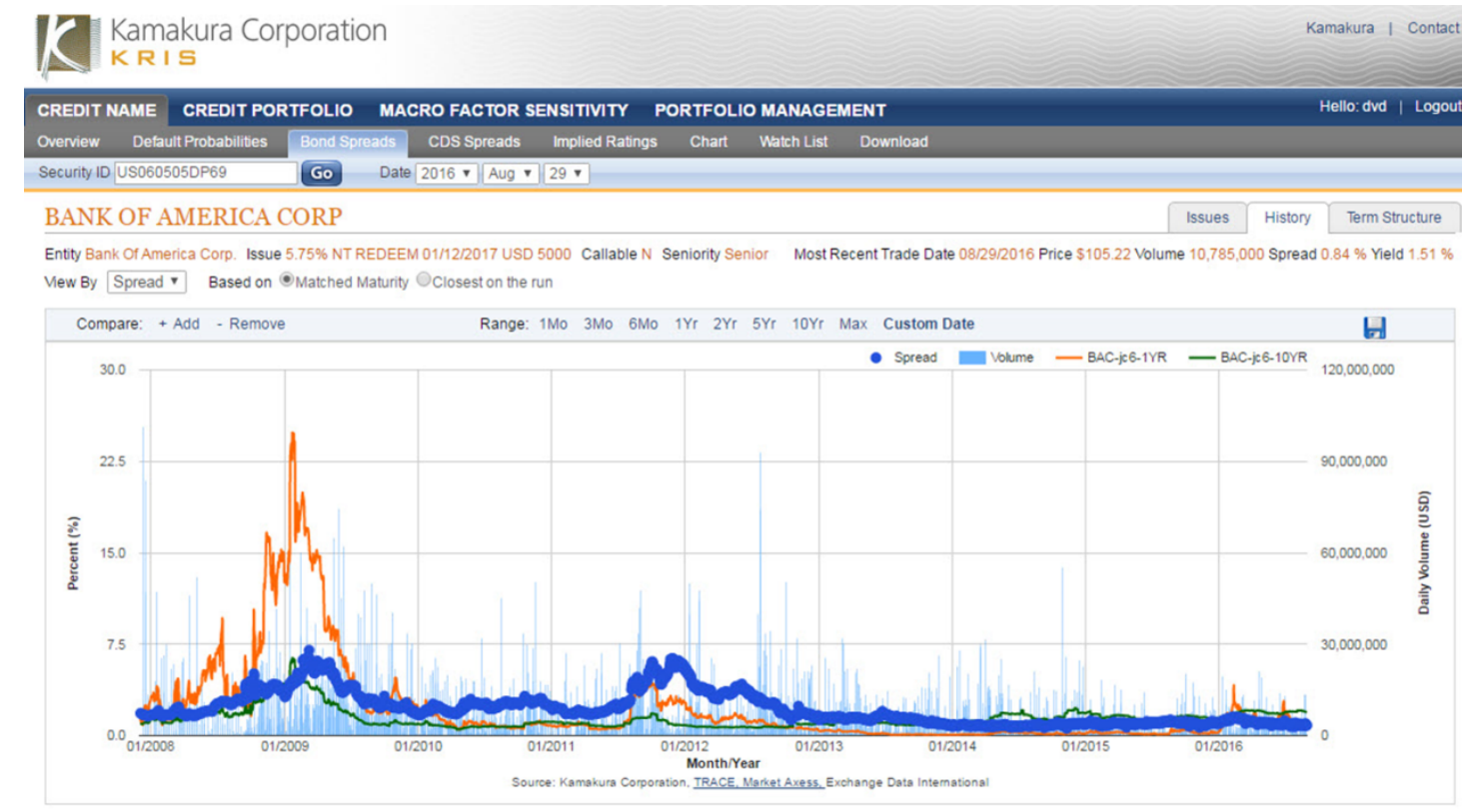


FIGURE 8

2008 BEHAVIOR OF CREDIT SPREAD ON A BOND MATURING ON 2-20-12, BUT ISSUED BY A FIRM (LEHMAN BROTHERS) THOUGHT TO BE TBTF UNTIL VIRTUALLY THE MOMENT IT WENT INTO LIQUIDATION

Kamakura Corporation

KRIS

CREDIT NAME GREDIT PORTFOLIO MACRO FACTOR SENSITIVITY PORTFOLIO MANAGEMENT

Implied Ratings Chart Watch List Download

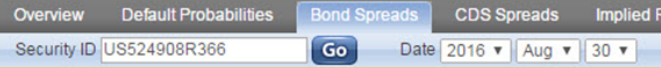

LEHMAN BROTHERS HOLDINGS INC

Entity Lehman Brothers Holdings Inc. Issue 6.50\% NT REDEEM 19/07/2017 USD 1000 Callable Y Seniority Senior Subordinate

View By Spread $\mathbf{v}$ Based on $\odot$ Matched Maturity $\bigcirc$ Closest on the run

Most Recent Trade Date 02/22/2012 Price \$0.00 Volume 690,000 Spread NA Yield NA

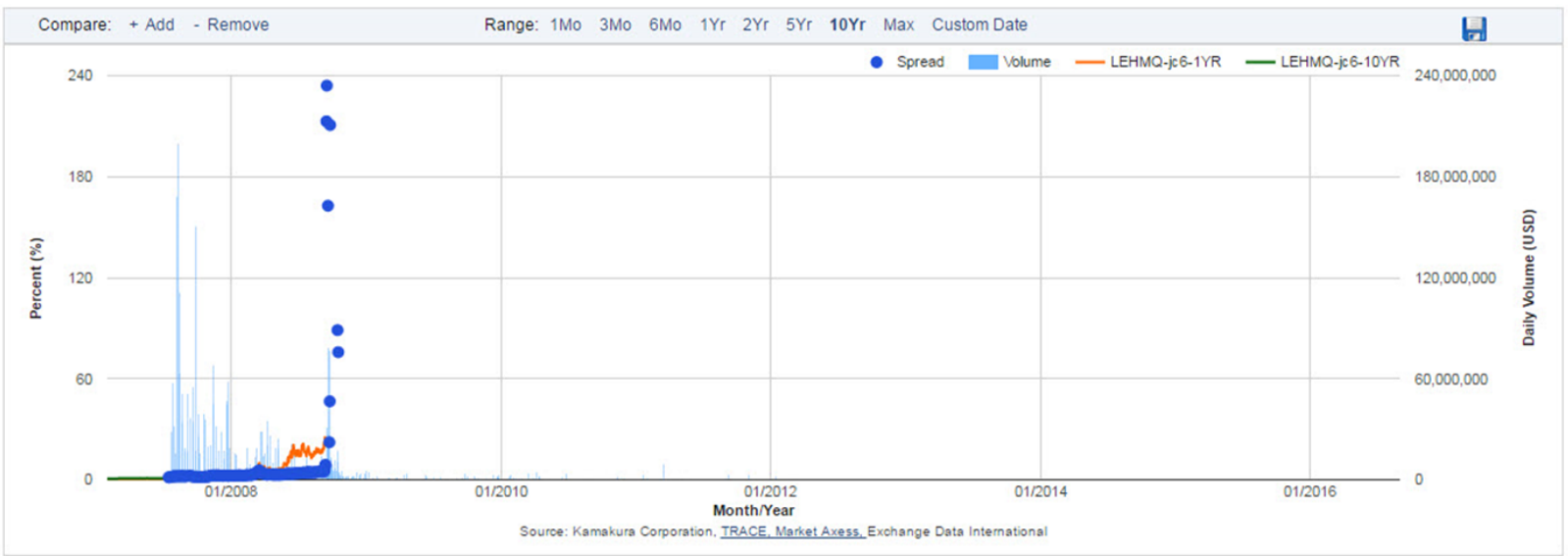


FIGURE 9

Kamakura Corporation

KRIS

CREDIT NAME CREDIT PORTFOLIO MACRO FACTOR SENSITIVITY PORTFOLIO MANAGEMENT

Hello: dvd | Logout

\section{Overview Default Probabilities Bond Spreads CDS Spreads Implied Ratings Chart Watch List Download}

Security ID US25152CMN38 Go Date 2016 V Aug V 30 V

DEUTSCHE BANK AG

Issues

History

Term Structure

Entity Deutsche Bank AG London Issue 6\% BD REDEEM 01/09/2017 USD 1000 - Ser 'A' Callable Y Seniority Senior

Vew By Spread $>$ Based on $\odot$ Matched Maturity $\bigcirc$ Closest on the run

Most Recent Trade Date 08/30/2016 Price $\$ 103.90$ Volume 6,407,000 Spread 1.42 \% Yield 2.03\%

Compare: + Add - Remove

Range: 1 Mo $3 \mathrm{Mo}^{2} \quad 6 \mathrm{Mo} \quad 1 \mathrm{Yr} \quad 2 \mathrm{Yr} \quad 5 \mathrm{Yr} \quad 10 \mathrm{Yr}$ Max Custom Date

田

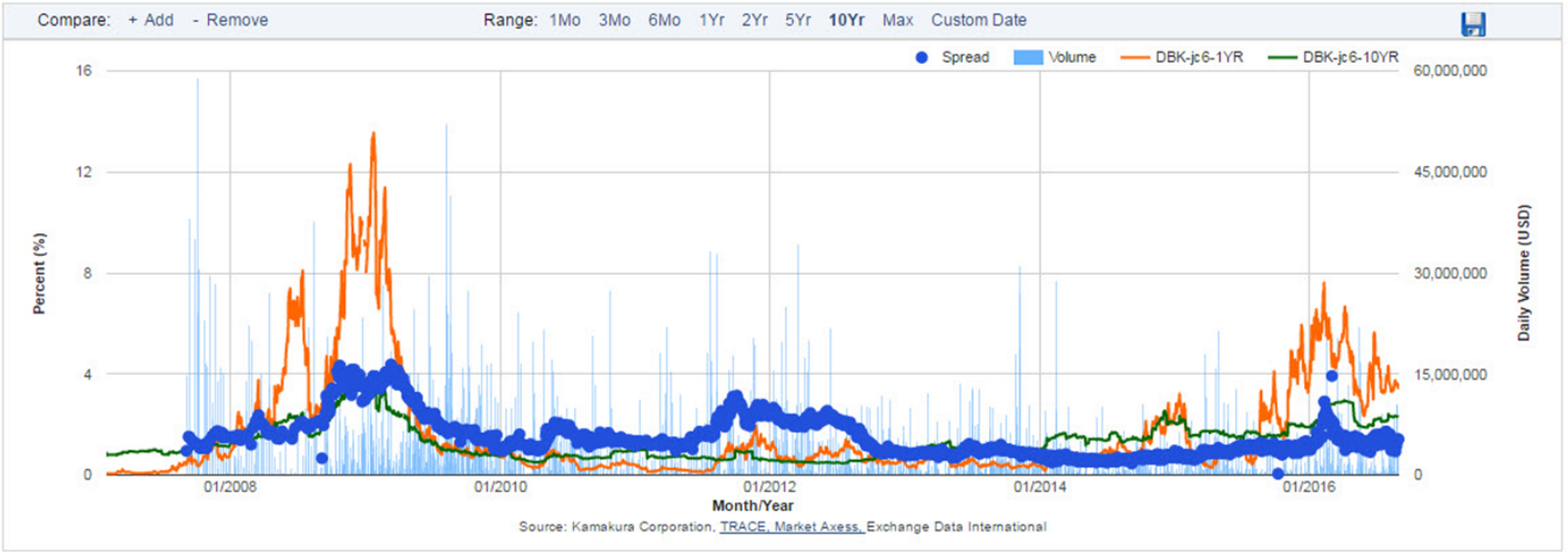

Surge in Orange preceded GFC. Credit spread moved much less than surges in other lines. Evidence of TBTF. 


\section{FIGURE 10}

Kamakura Corporation

KRIS

CREDIT NAME CREDIT PORTFOLIO MACRO FACTOR SENSITIVITY PORTFOLIO MANAGEMENT

Overview Default Probabilities Bond Spreads CDSSpreads Implied Ratings Chart Watch List Download

Security ID US25152CMN38

Go

DEUTSCHE BANK AG

Issues

History

Term Structure

Entity Deutsche Bank AG London Issue 6\% BD REDEEM 01/09/2017 USD 1000 - Ser 'A' Callable Y Seniority Senior

View By Spread $\mathbf{~ B a s e d ~ o n ~} \odot$ Matched Maturity $\bigcirc$ Closest on the run

Most Recent Trade Date 10/14/2016 Price \$102.63 Volume 6,010,000 Spread 2.29 \% Yield $2.90 \%$

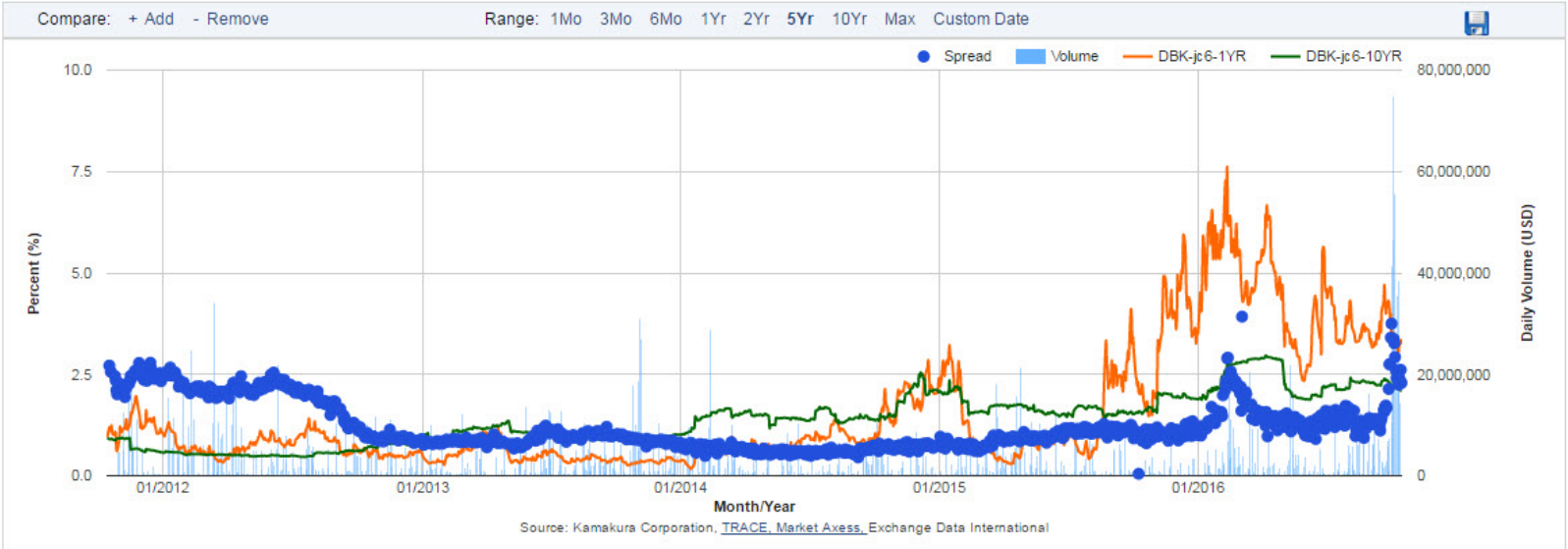




\section{FIGURE 11}

Kamakura Corporation

KRIS

CREDIT NAME CREDIT PORTFOLIO MACRO FACTOR SENSITIVITY PORTFOLIO MANAGEMENT

\section{Chart Watch List Download}

Overview Default Probabilities

Security ID US22546QAD97 Go Date 2016 V Aug $\mathbf{~} 30$

CREDIT SUISSE GROUP

Entity Credit Suisse AG (New York) Branch Issue 5.40\% NT REDEEM 14/01/2020 USD 2000 Callable N Seniority Senior Subordinate

Vew By Spread $\mathbf{V}$ Based on $\odot$ Matched Maturity $\odot$ Closest on the run

Most Recent Trade Date 08/30/2016 Price \$109.87 Volume 5,004,000 Spread 1.37\% Yield 2.33\%

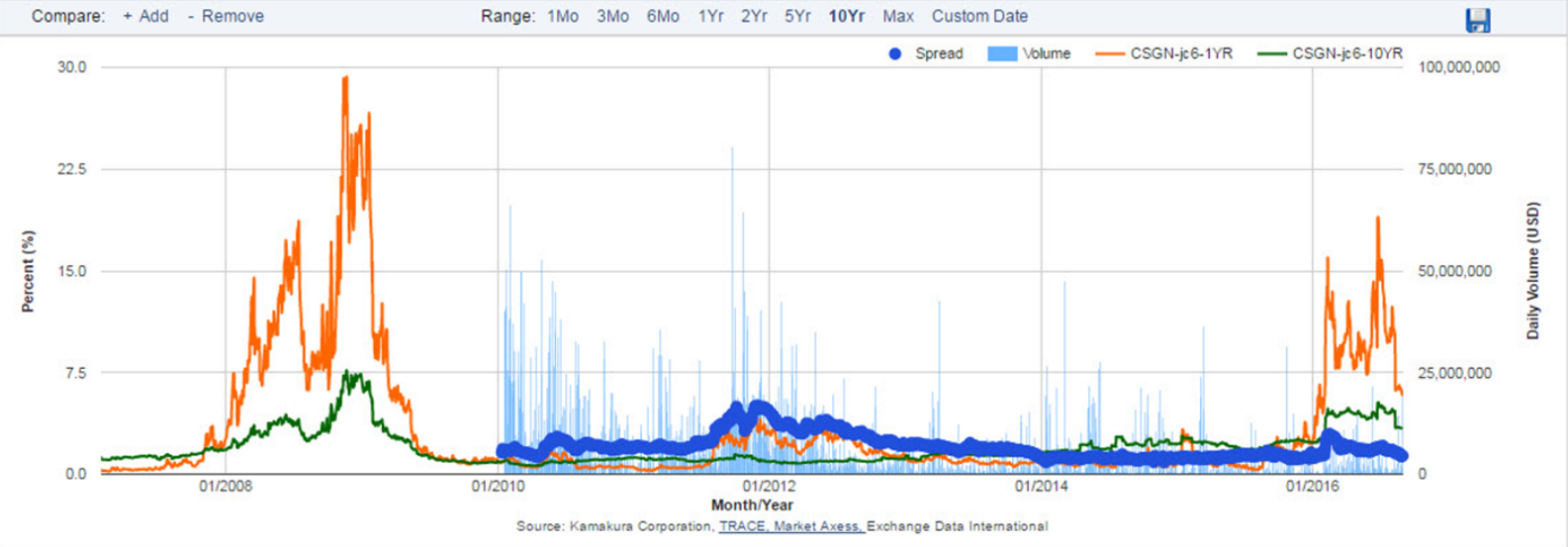

- No US debt in GFC

- TBTF pattern today 


\section{FIGURE 12}

Kamakura Corporation

KRIS

CREDIT NAME CREDIT PORTFOLIO MACRO FACTOR SENSITIVITY PORTFOLIO MANAGEMENT

Overview Default Probabilities Bond Spreads CDSSpreads Implied Ratings Chart Watch List Download

Security ID US22546QAT40 Go Date 2016 V Oct $\mathbf{V} 14$ V

\begin{tabular}{|l|l|l|l|}
\hline CREDIT SUISSE GROUP & Issues & History & Term Structure \\
\hline
\end{tabular}

Entity Credit Suisse AG (New York) Branch Issue 1.75\% NT REDEEM 29/01/2018 USD 250000 Callable N Seniority Senior

View By Spread $\mathbf{V}$ Based on $\odot$ Matched Maturity $\bigcirc$ Closest on the run

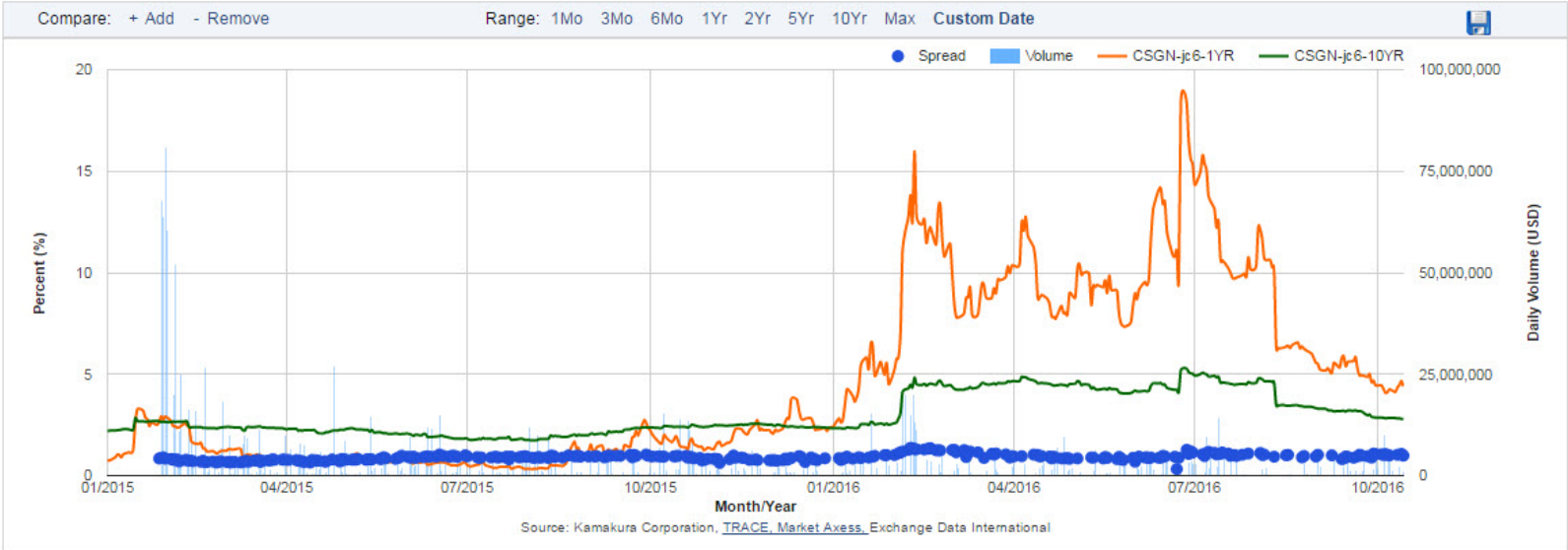

UBS GROUP AG

Entity UBS Group Funding (Switzerland) AG Issue 2.65\% NT REDEEM 01/02/2022 USD 200000 - Reg S Callable N Seniority Senior

Most Recent Trade Date 08/01/2017 Price \$100.13 Volume 650,000 Spread $0.89 \%$ Yield $2.62 \%$

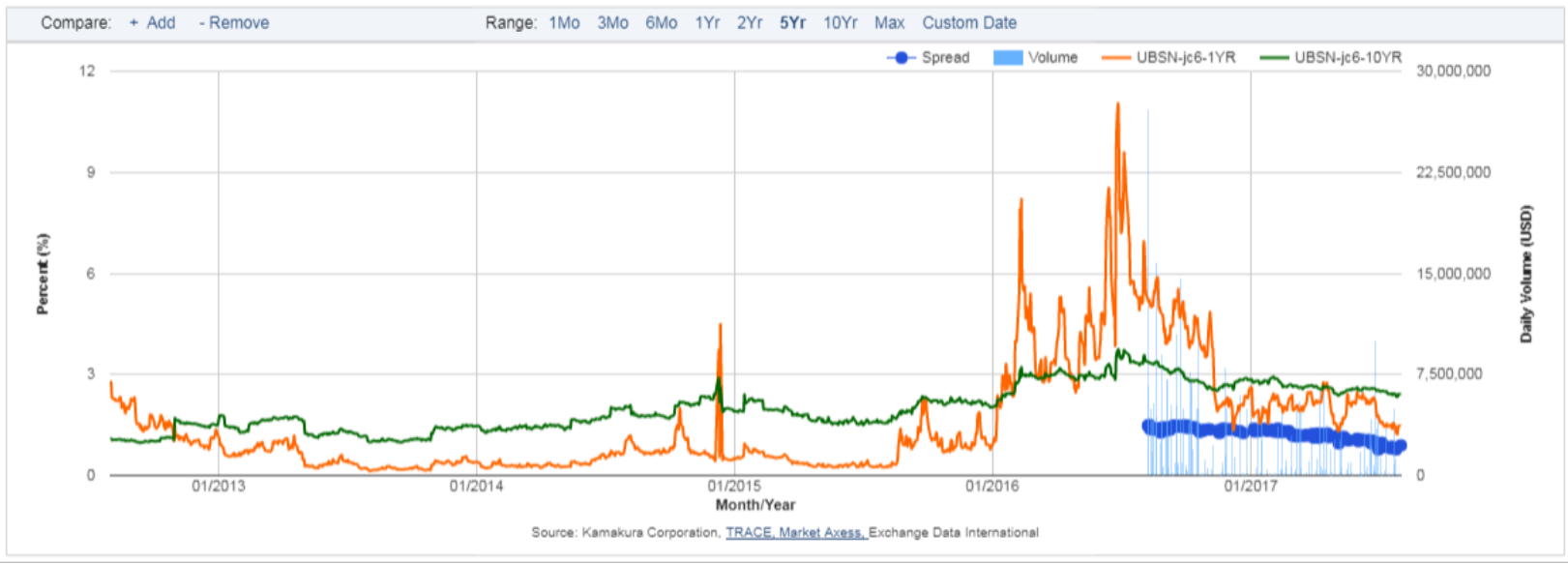




\section{FIGURE 13}

Kamakura Corporation

KRIS

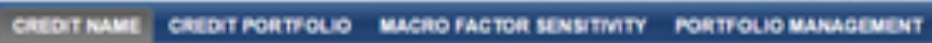

Kansora 1 Cunses

keve ond i tequ

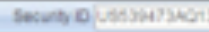

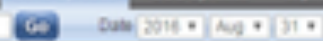

LIONDS BANKING GROUP PLC

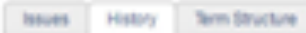

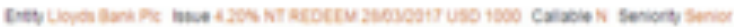

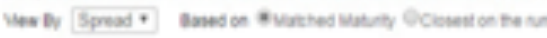

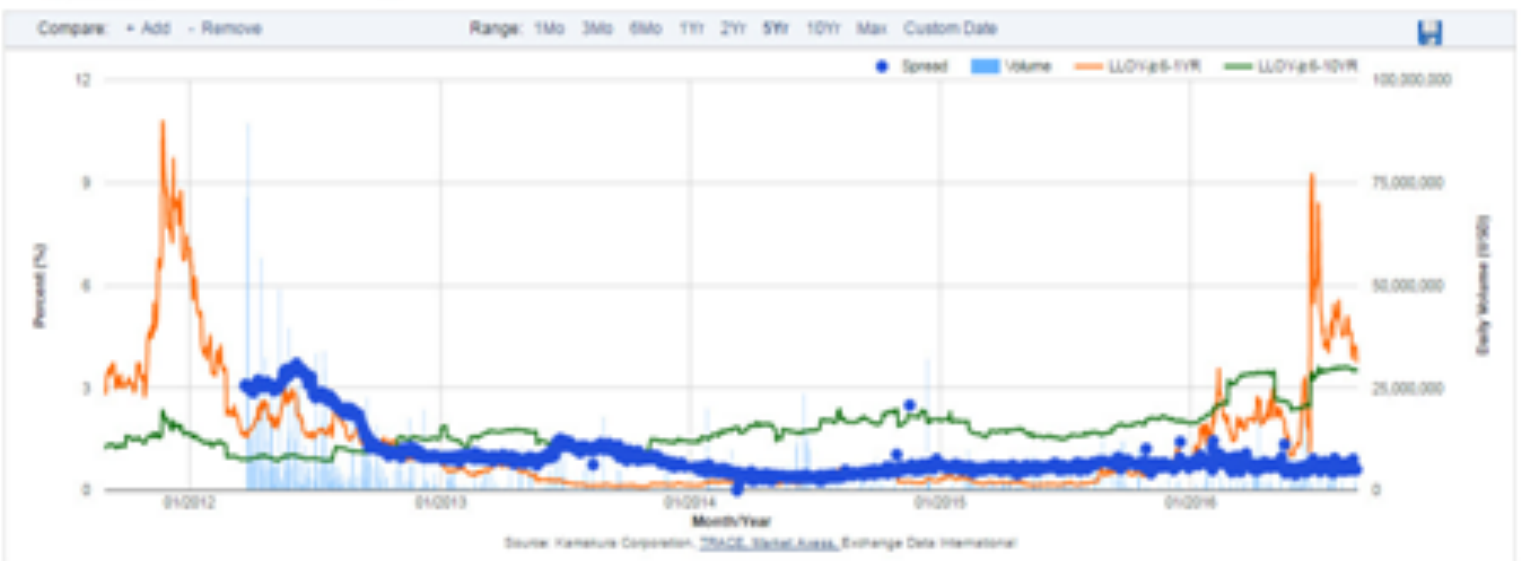




\section{FIGURE 14}

Kamakura Corporation

KRIS

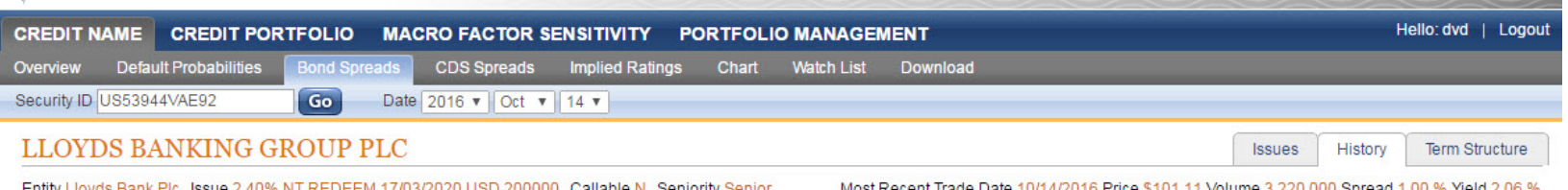

Entity Lloyds Bank PIC Issue 2.40\% NT REDEEM 17/03/2020 USD 200000 Callable N Seniority Senior $\quad$ Most Recent Trade Date 10/14/2016 Price \$101.11 Volume 3,220,000 Spread 1.00 \% Yield 2.06 \% View By Spread $\mathbf{v}$ Based on $\odot$ Matched Maturity $O$ Closest on the run

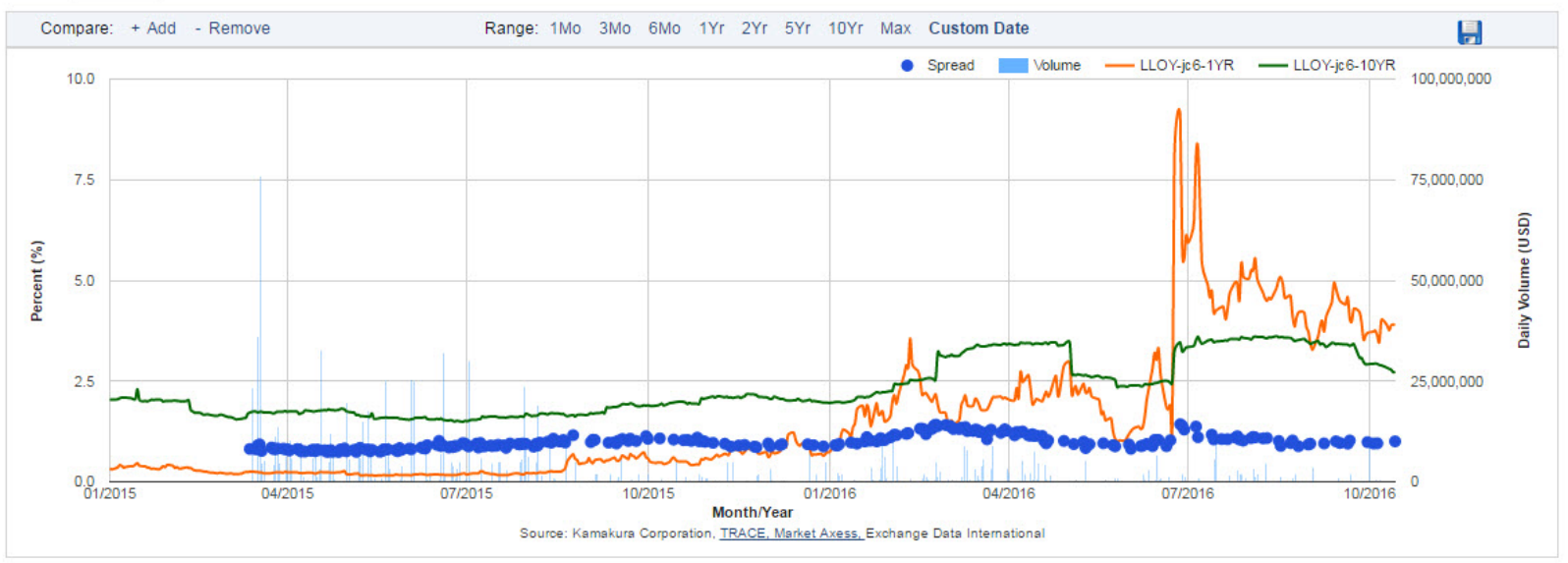




\section{FIGURE 15}

\section{BANCO SANTANDER SA}

Entity Santander Holdings USA Inc Issue 4.50\% NT REDEEM 17/07/2025 USD 2000 Callable Y Seniority Senior

Most Recent Trade Date 082822017 Price \$105.43 Volume 229,000 Spread $1.64 \%$ Yield 3.68\%

View By Spread - Based on $\odot$ Matched Maturity. Closest on the run Volume weighted spread based on actual trades

Compare: + Add - Remove $\quad$ Range: $\underline{1 \mathrm{Mo}} \underline{3 \mathrm{Mo}} \underline{6 \mathrm{Mo}} \underline{1 \mathrm{Yr}} \underline{2 \mathrm{Yr}} \underline{5 \mathrm{Yr}} \underline{10 \mathrm{Yr}} \underline{\text { Max }}$ Custom Date

${ }_{4} \longrightarrow$ Spread $\quad$ Volume - SAN-jc6-1YR - SAN-jc6-10YR ${ }_{40,000,000}$

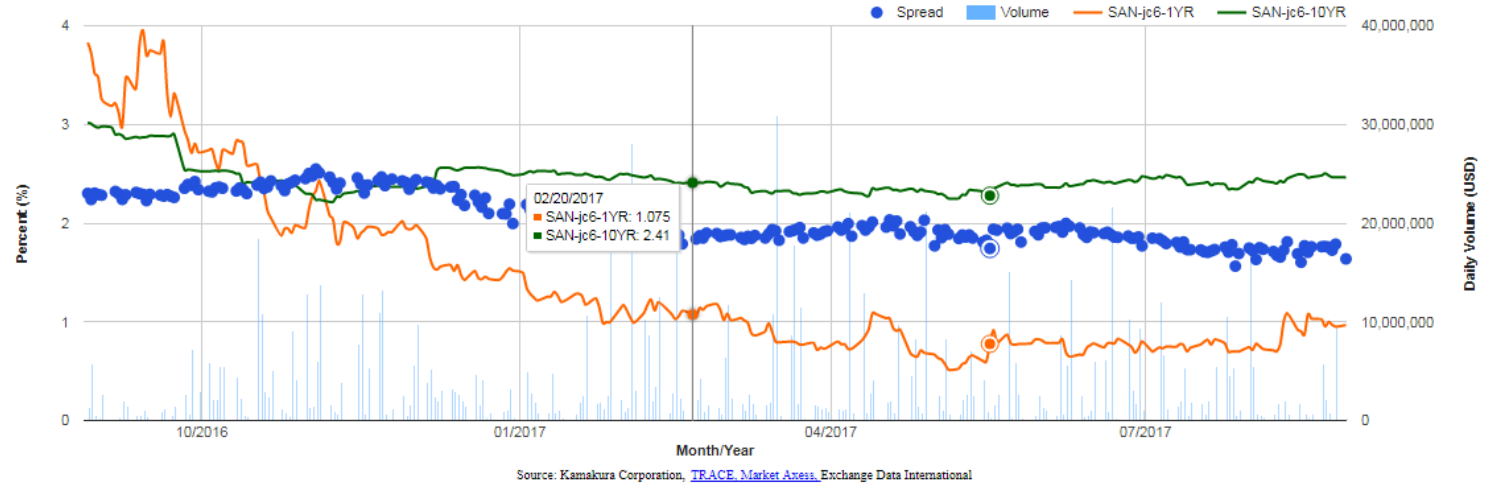




\section{FIGURE 16}

\section{BBVA}

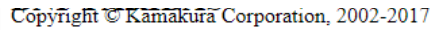

Entity BBV Intemational Finance Issue 7\% NT REDEEM 01/12/2025 USD 100000 Callable N Seniority Senior Subordinate Most Recent Trade Date 08/28:2017 Price \$118.83 Volume 32,000 Spread 2.21 \% Yield 4.27\%

View By Spread $\mathbf{v}$ Based on Matched Maturity Closest on the run Volume weighted spread based on actual trades

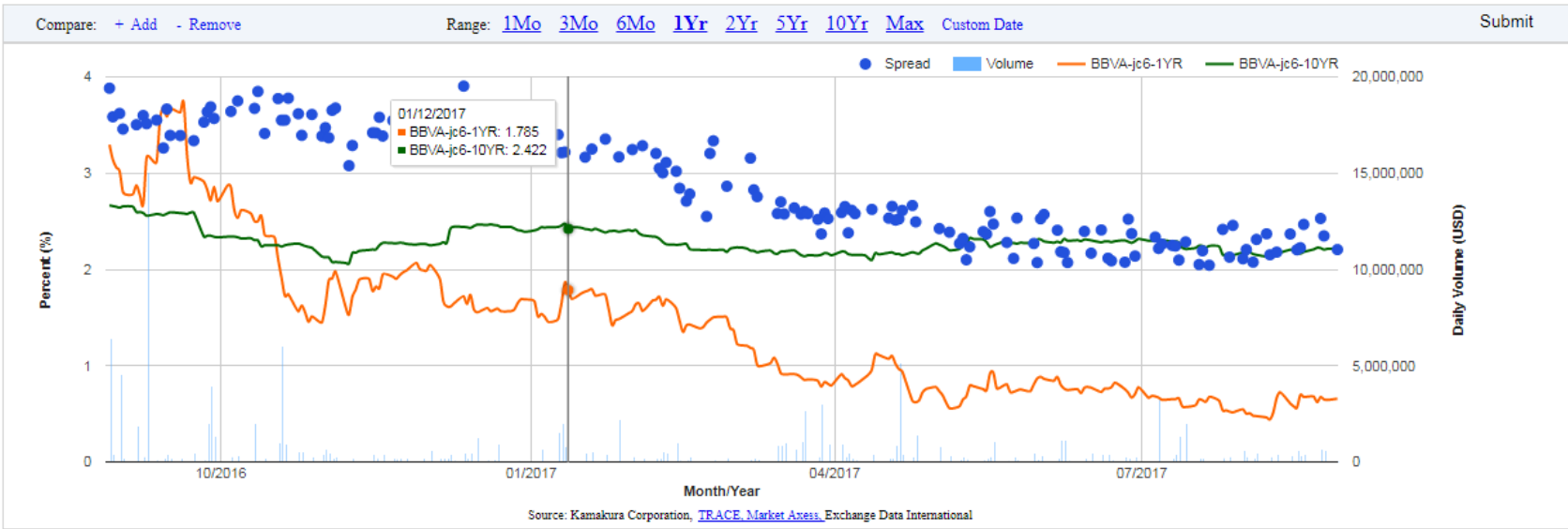




\section{FIGURE 17}

\section{HSBC HOLDINGS, PFC}

| Cop̀ỹright đ Kämakưữa Corporation, 2002-2017

Entity HSBC Holdingsplc Issue 4.25\% NT REDEEM 14/03/2024USD 200000 CallableN Seniority Senior Subordinate

Most Recent Trade Date 08/28/2017Price $\$ 104.99$ Volume 3,044,000 Spread 1.46 \% Yield $3.39 \%$

View By Spread Basedon $\bullet_{\text {Matched Maturity }}$ Closeston the run Volume weighted spread based on actual trades

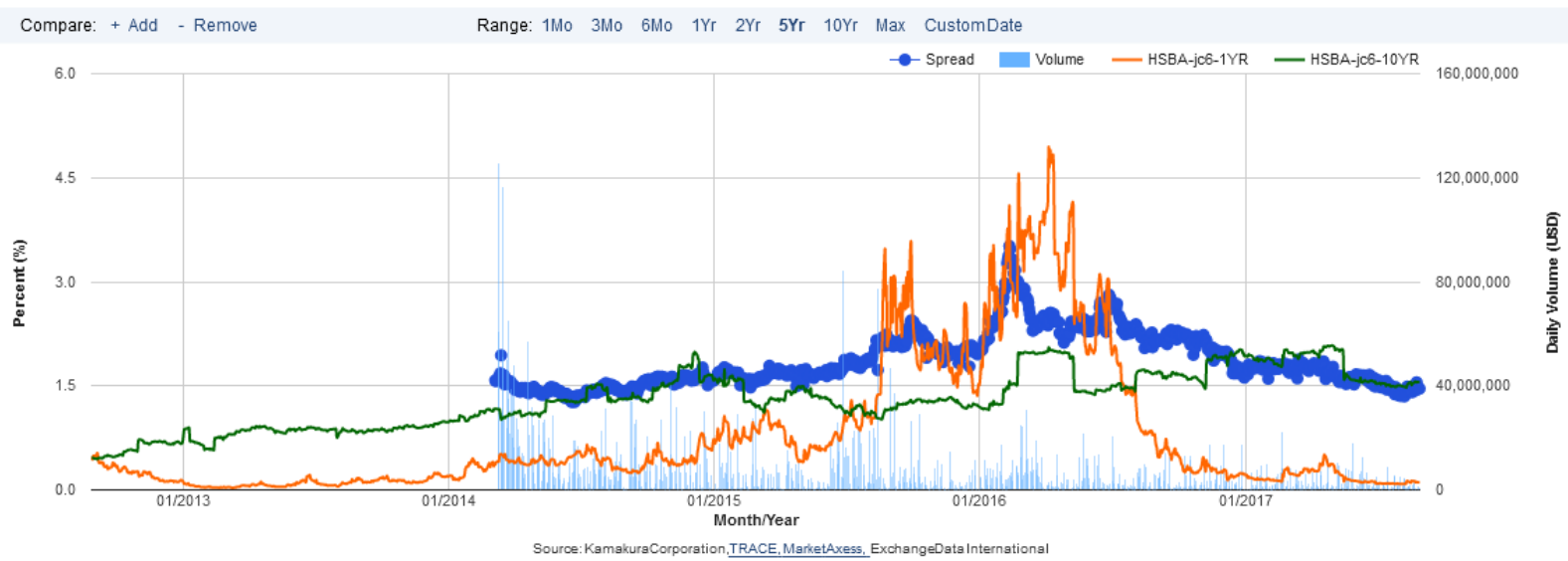




\section{FIGURE 18}

\section{BNP PARIBAS}

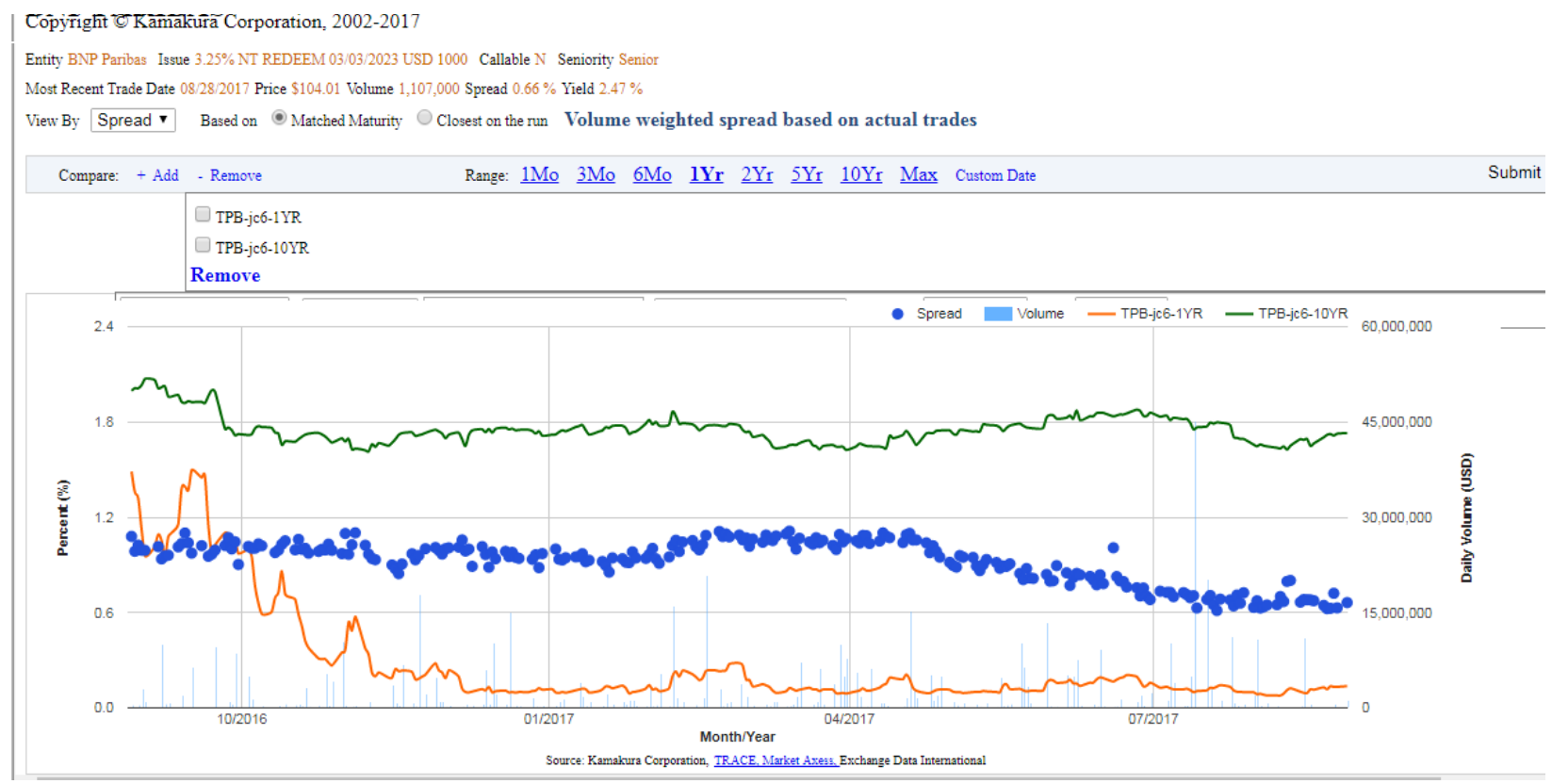


FIGURE 19

WHY THE REVOLVING DOOR DOES SO MUCH BUSINESS: MAXIMUM SALARIES OF TOP REGULATORS COMPARED WITH INCOMES EARNED BY TOP MANAGERS IN THE PRIVATE SECTOR OVER TIME

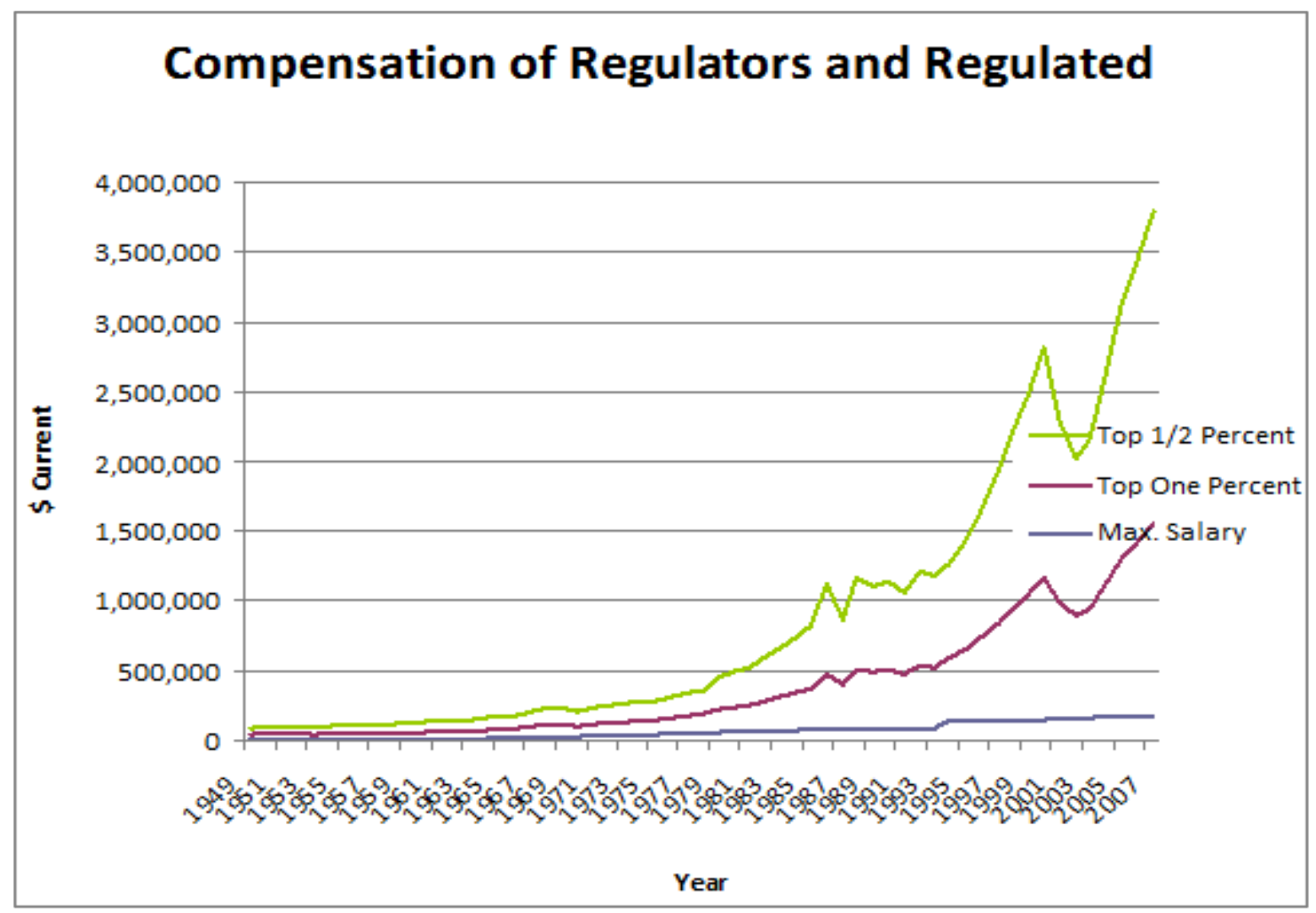

Source: Ferguson and Johnson (2010). 
FIGURE 20

HOW THE PRICE OF BANCO POPULAR'S COCO BONDS DECLINED AS THE

BANK HEADED FOR CLOSURE

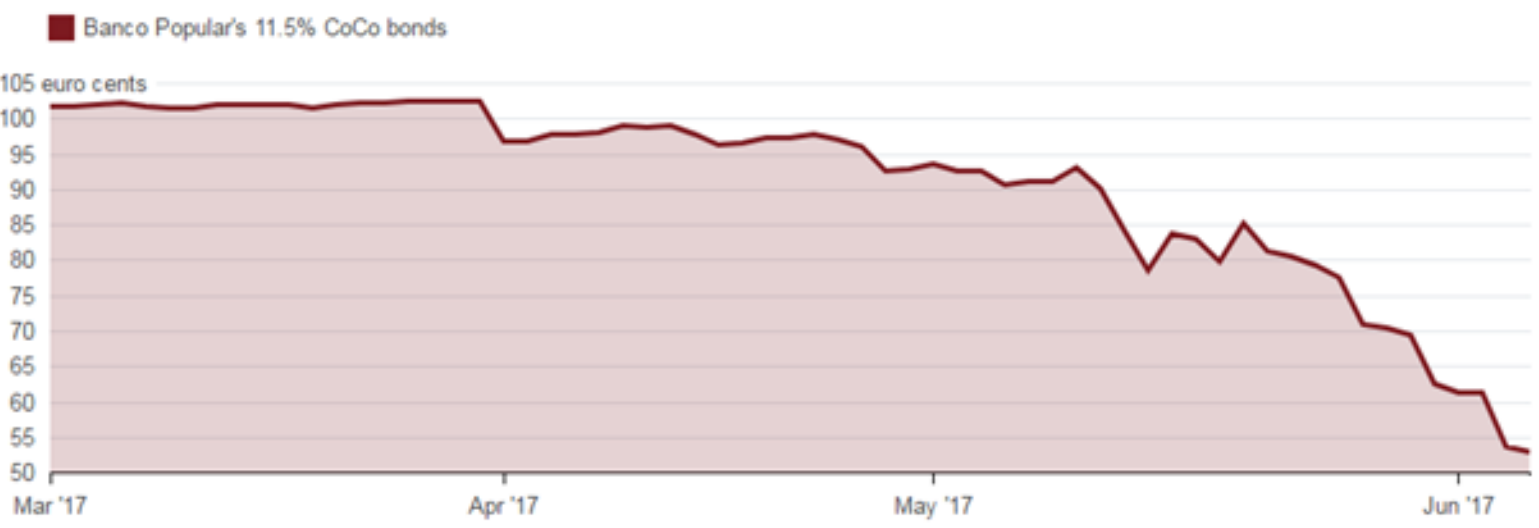


FIGURE 21

HOW THE PRICES OF BANCO POPULAR STOCK AND BONDS BEHAVED IN ITS FINAL MONTHS

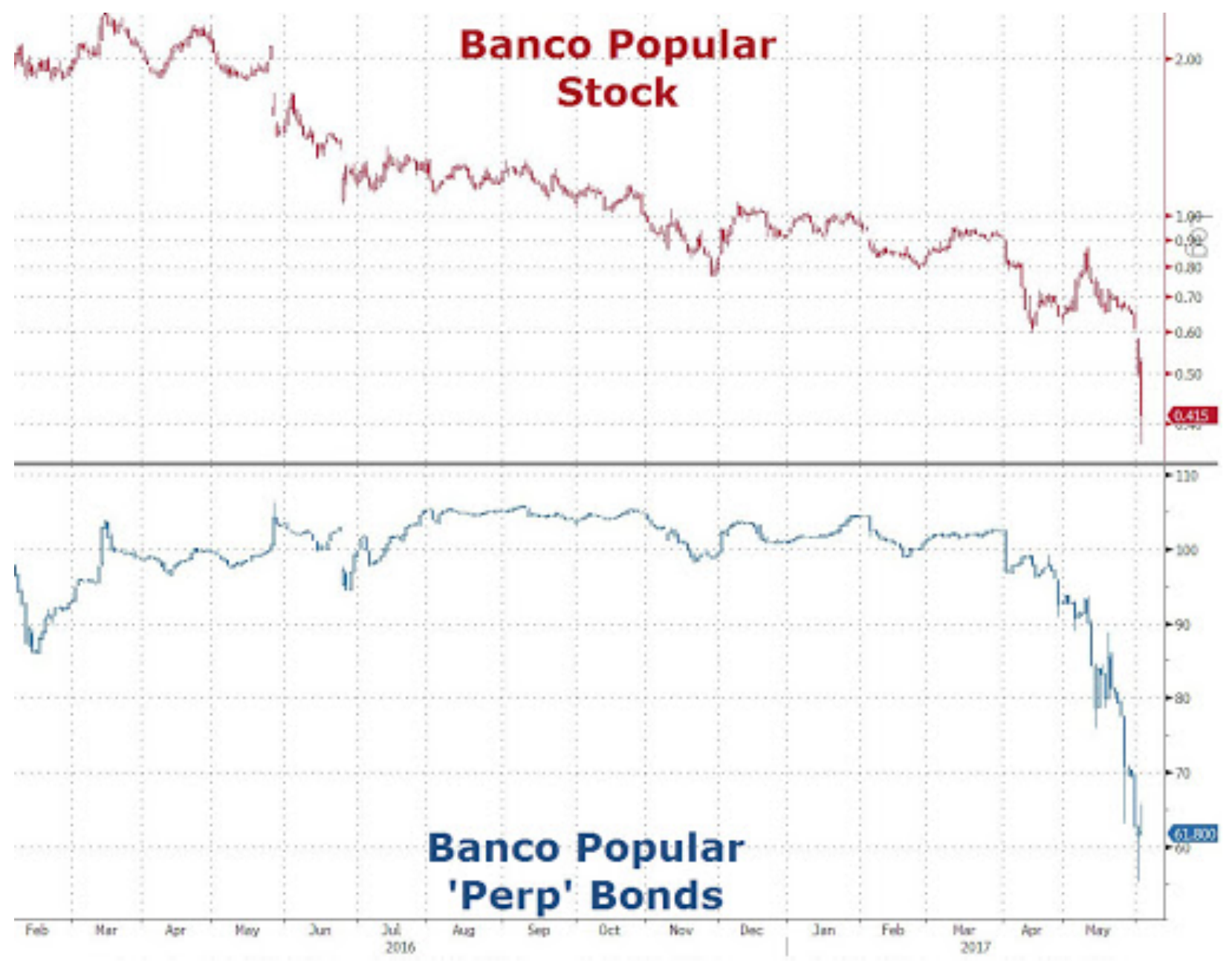

Source: The Financial Times 
TABLE 22

THE FALL, RISE, AND FALL AGAIN OF DEUTSCHE'S

STOCK PRICE IN THE LAST YEAR

Deutsche Bank Aktiengesellschaft (DBK.F)

$13.49+0.34(2.57 \%)$

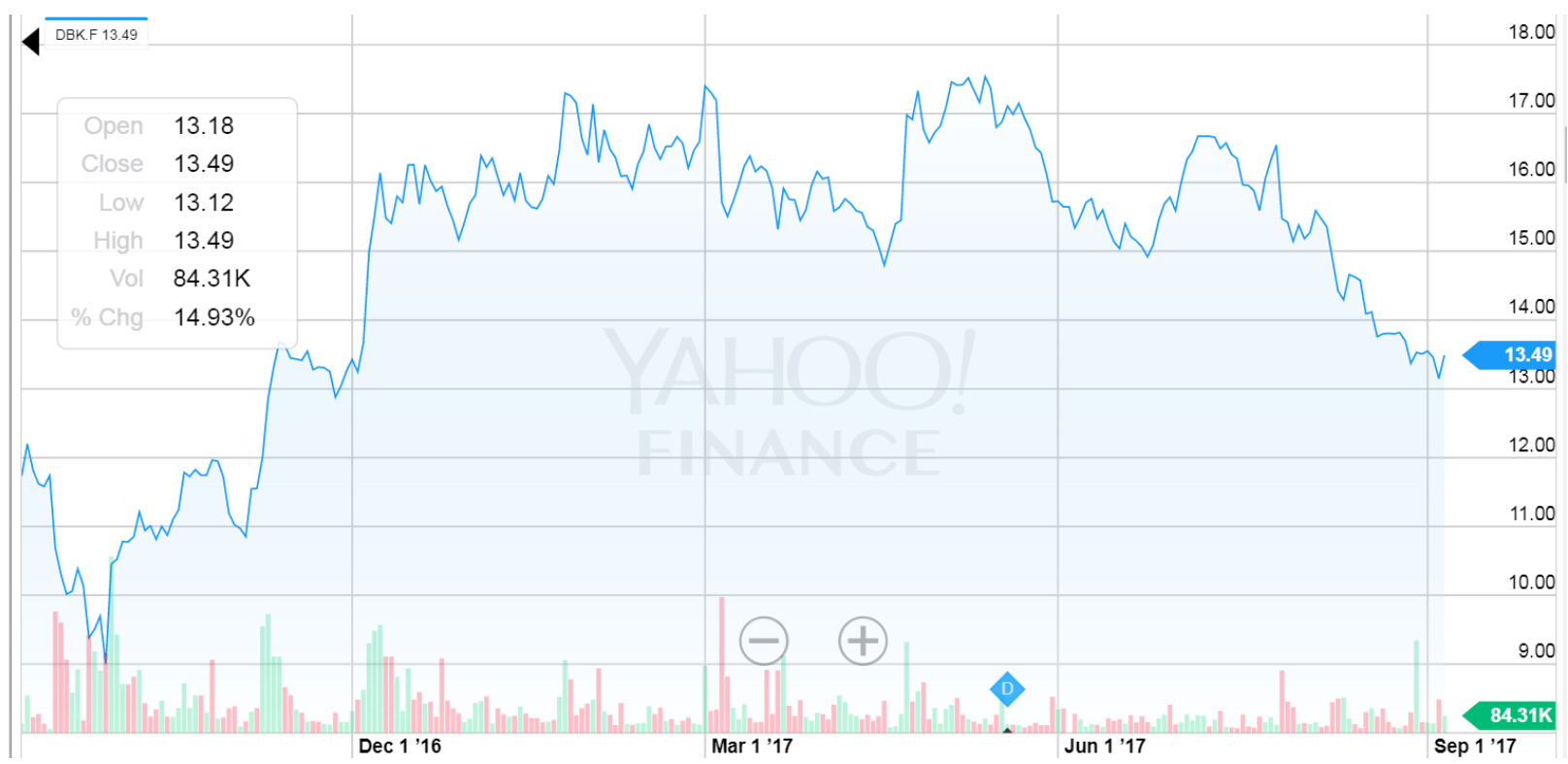

Source: Yahoo Finance 
FIGURE 23

COMPARISON OF ONE-YEAR “KDP” AT DBK WITH MEDIAN KDP OF US BANKS, mid-JUNE 2012 THROUGH mid-JUNE 2017

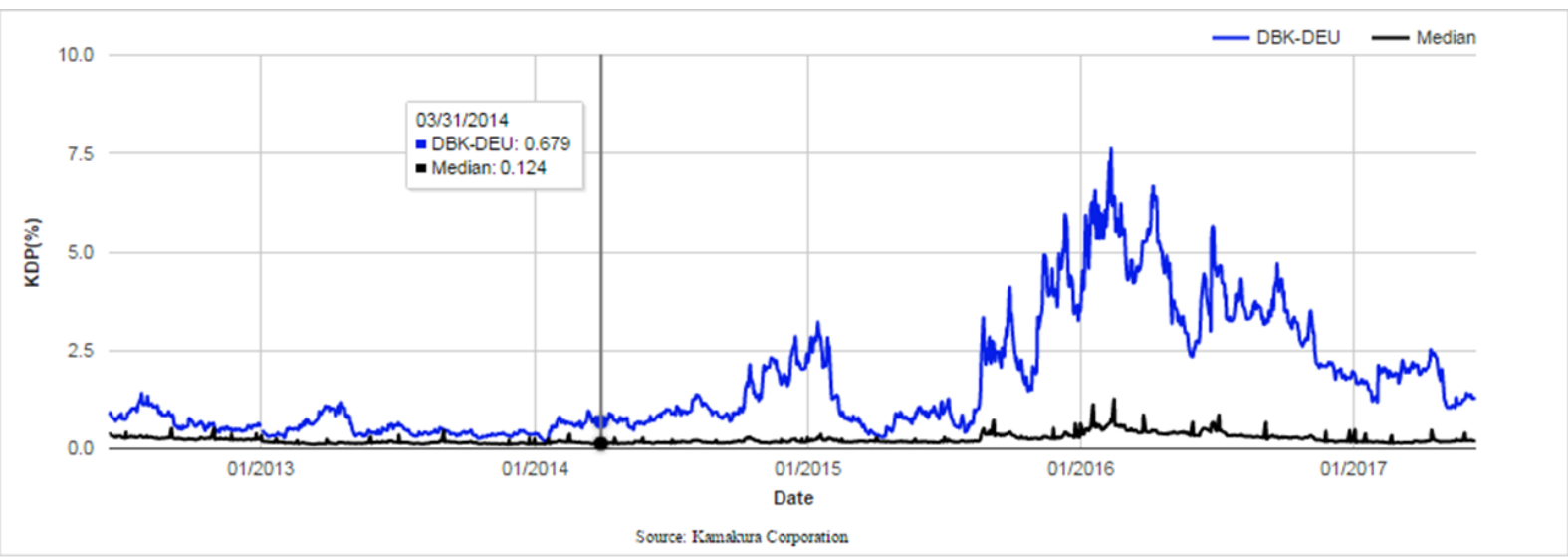


TABLE 1

ESTIMATED KDPS IN MARCH, 2017 FOR THE 11 WEAKEST BANKS OPERATING IN THE UNITED STATES (REGARDLESS OF HEADQUARTERS LOCATION) THAT WERE SUBJECT TO THE FEDERAL RESERVE'S CCAR STRESS TESTING IN 2016.

\begin{tabular}{|c|c|c|c|c|c|c|}
\hline Ticker & Company & Country & S\&P Rating & $1 \mathrm{yr}$ & $3 \mathrm{yr}$ & $10 \mathrm{yr}$ \\
\hline DBK & DEUTSCHE BANK AG & DEU & $\mathrm{BBB}+$ & 2.06 & 6.49 & 22.90 \\
\hline SAN & BANCO SANTANDER SA & ESP & A- & 0.86 & 4.11 & 20.83 \\
\hline BBVA & BBVA & ESP & $\mathrm{BBB}+$ & 1.01 & 4.05 & 19.75 \\
\hline 8306 & MITSUBISHI UFJ FINANCIAL GRP & JPN & A & 0.49 & 3.43 & 19.79 \\
\hline ALLY & ALLY FINANCIAL INC & USA & $\mathrm{BB}+$ & 0.63 & 3.17 & 19.35 \\
\hline 601988 & BANK OF CHINA LTD & $\mathrm{CHN}$ & A & 0.82 & 2.83 & 15.28 \\
\hline HSBA & HSBC HLDGS PLC & GBR & A & 0.22 & 2.34 & 17.69 \\
\hline $\mathrm{RF}$ & REGIONS FINANCIAL CORP & USA & BBB & 0.14 & 1.71 & 14.61 \\
\hline HBAN & HUNTINGTON BANCSHARES & USA & BBB & 0.14 & 1.63 & 14.13 \\
\hline ТРВ & BNP PARIBAS & FRA & $\mathrm{A}$ & 0.11 & 1.57 & 15.27 \\
\hline
\end{tabular}

Note: The table ranks banks by the size of their three-year cumulative default probabilities on 39-17. 
TABLE 2

CREDIT DEFAULT SWAP SPREADS ON 7-7-17 FOR THE SAME ELEVEN BANKS

\begin{tabular}{|c|c|c|c|c|c|c|c|c|c|c|c|c|}
\hline Ticker & Company & Country & Rating & $\begin{array}{l}1 \\
\text { Month }\end{array}$ & $\begin{array}{l}3 \\
\text { Month }\end{array}$ & $\begin{array}{l}1 \\
\text { year }\end{array}$ & $\begin{array}{l}2 \\
\text { year }\end{array}$ & $\begin{array}{l}3 \\
\text { year }\end{array}$ & $\begin{array}{l}4 \\
\text { year }\end{array}$ & $\begin{array}{l}5 \\
\text { year }\end{array}$ & $\begin{array}{l}7 \\
\text { year }\end{array}$ & $\begin{array}{l}10 \\
\text { year }\end{array}$ \\
\hline DBK & Deutsche Bank AG & DEU & A- & 0.57 & 0.62 & 0.63 & 0.82 & 0.78 & 0.79 & 0.84 & 1.15 & 1.29 \\
\hline 601988 & Bank of China LTD & $\mathrm{CHN}$ & A- & 0.58 & 65 & 0.63 & 0.71 & 0.65 & 0.65 & 0.67 & 0.9 & 1.05 \\
\hline SAN & Banco Santander SA & ESP & A- & 0.22 & 0.25 & 0.45 & 0.85 & 0.85 & 0.87 & 1 & 1.56 & 1.49 \\
\hline BBVA & BBVA & ESP & $\mathrm{BBB}+$ & 0.2 & 0.22 & 0.39 & 0.74 & 0.75 & 0.77 & 0.9 & 1.44 & 1.38 \\
\hline 8306 & Mitsubishi UFJ Financial GRP & JPN & A- & 0.12 & 0.15 & 0.34 & 0.77 & 0.77 & 0.81 & 0.95 & 1.46 & 1.41 \\
\hline ALLY & Ally Financial INC & USA & $\mathrm{BB}+$ & 0.19 & 0.22 & 0.34 & 0.64 & 0.69 & 0.75 & 0.89 & 1.47 & 1.46 \\
\hline HBAN & Huntington Bancshares & USA & $\mathrm{BBB}$ & 0.06 & 0.07 & 0.12 & 0.37 & 0.42 & 0.49 & 0.62 & 1.05 & 1.04 \\
\hline $\mathrm{RF}$ & Regions Financial Corp & USA & $\mathrm{BBB}$ & 0.06 & 0.07 & 0.12 & 0.36 & 0.42 & 0.49 & 0.62 & 1.05 & 1.05 \\
\hline KEY & KEYCORP & USA & $\mathrm{BBB}+$ & 0.07 & 0.08 & 0.08 & 0.23 & 0.29 & 0.38 & 0.51 & 0.87 & 0.92 \\
\hline ТPB & BNP Paribas & FRA & A & 0.05 & 0.06 & 0.07 & 0.25 & 0.36 & 0.49 & 0.64 & 1.01 & 1.1 \\
\hline HSBA & HSBC HLDGS PLC & GBR & A & 0.06 & 0.07 & 0.06 & 0.17 & 0.25 & 0.36 & 0.51 & 0.84 & 0.92 \\
\hline
\end{tabular}


TABLE 3

HIGH CORRELATION OF KDPS AT MAJOR US AND EUROPEAN MEGABANKS

\begin{tabular}{|c|c|}
\hline Bank Pair & Correlation Coefficient in KRIS data \\
\hline BAC and C & .94 \\
\hline BAC and JPM & .80 \\
\hline BAC and GS & .93 \\
\hline BAC and MS & .94 \\
\hline BAC and DBK & .51 \\
\hline BAC and BBVA & .73 \\
\hline BAC and UBS & .60 \\
\hline BAC and CSGN & \\
\hline
\end{tabular}

Source: KRIS posted these figures on 3-17-17. 


\section{REFERENCES}

Adrian, Tobias, and Aditya Narain, 2017. "Safe and Sound: International Financial Regulators Help Ensure the Safety and Soundness of Diverse Financial Systems," Finance and Development (September), 14-17.

Burne, Kathy, 2015. "Big Winners as Fed Raises Rates: Foreign Banks,” Wall Street Journal (December 23). https://www.wsj.com/articles/big-winners-as-fed-raises-rates-foreignbanks-1450909844.

Cowen, Tyler, 2011. "Euro vs. Invasion of the Zombie Banks," (http://www.nytimes.com/2011/04/17/business/17view.html), The New York Times (April 17).

Demirgüç-Kunt, Asl1, Luc Laeven, and Edward Kane, 2015. "Deposit Insurance Around the World: A Comprehensive Analysis and Database," Journal of Financial Stability, 20 (October), pp. 155-183.

Demirgüç-Kunt, Asl1, and Harry Huisinga, 2010. “Are Banks Too Big to Fail or Too Big to Save?: International Evidence from Equity Prices and CDS Spreads," Policy Research Working Paper 5360, The World Bank.

Dowd, Kevin (2015). “Central Bank Stress Tests: Mad, Bad, and Dangerous,” Cato Journal, 35 No. 3 (Fall), 507-524.

Ferguson and Johnson (2010), “When Wolves Cry Wolf,” INET Paper, King's College, Cambridge University, 2010. https://www.ineteconomics.org/uploads/papers/INETC@K-Paper-Session-8-Ferguson-Rob-Johnson.pdf. 
Gehrig, Thomas and Maria Chiara Iannino, 2017. "Did the Basel Process of Capital Regulation Enhance the Resiliency of European Banks?" Working Paper, University of Vienna (June, 25).

Giacché, Vladimiro, 2017. "The Real Cause of the Italian Bank Bailouts and Euro Banking Troubles," Blog on the Institute for New Economic Thinking website (July 19).

Hale, Thomas, 2017. “Investors sue Brussels over Banco Popular Sale,” Financial Times (August 17). http://www.ft.com/content/696000364-8335-11e7-c5b903247afa.

Jones, Marc, 2017. “Central Banks Need Joint Plans for Future Funding Crises: BIS,” Reuters Business News (April 6).

Kane, Edward J., 1989. The S\&L Mess: How Did it Happen?, Washington: The Urban Institute Press. , 2003. "What Lessons Might Crisis Countries in Asia and Latin American Have Learned from the S\&L Mess?," Business Economics, 38 (January), pp. 21-30. , 2016a. "A Theory of How and Why Central-Bank Culture Supports Predatory RiskTaking at Megabanks," Atlantic Economic Journal, 44, pp. 51-71. ,2016b. "Ethics versus Ethos in US and UK Megabanking," Journal of Financial Services Research (forthcoming).

McLannahan, Ben, Kara Scannell, and Gary Silverman, 2017. “Donald Trump’s Debt to Deutsche Bank," Financial Times (Sept. 3). http://www.ft.com/content/8c6d9dca-882c11e7-bf50-e1c239b45787.

Nestler, Franz, 2016. “Spekulationen über Staatshilfe: Ihre Ghoesse Wird die Deutsche Bank nicht Schuetzen,” [“Speculation on State Aid: Its Size Won’t Protect Deutsche Bank”] Frankfurter Allegemeine Zeitung (September 28). 
http://www.faz.net/aktuell/wirtschaft/spekulationen-ueber-staatshilfe-ihre-groesse-wirddie-deutsche-bank-nicht-schuetzen-14457841.html.

Neumyer, Tory, 2017. “The Finance 202: Hard-Line Conservatives Endanger Wall Street Agenda," Washington Post (September 8).

https://www.washingtonpost.com/news/powerpost/paloma/the-finance202/2017/09/08/the-finance-202-hard-line-conservatives-endanger-wall-streetagenda/59b1ac4830fb045176650bbb/?utm term=.da643547a679.

Onaran, Yalman, 2017. "Zombie Banks: How the Undead Weigh Down Europe's Economy," Bloomberg Quick Take (July 11).

Smith, Robert, 2017. "Why Banco Popular's Credit Default Swaps are Getting Messy," Financial Times (Sept. 2). http://www.ft.com/content/a4449092-6bb8-11e7-bfeb$33 \mathrm{fe} 0 \mathrm{c} 5 \mathrm{~b} 7 \mathrm{eaa}$.

Thomas, Landon, and Chad Bray, 2016. “Deutsche Bank Denies It Sought Germany’s Help in Dispute with the US," New York Times (September 27), B3.

Wall, Larry D., 2015. "The Impact of Regulation on Monetary Policy," Notes from the Vault, Center for Financial Innovation and Stability, Federal Reserve Bank of Atlanta (January). Yellen, Janet L., 2017. "Financial Stability a Decade After the Onset of the Crisis," Presentation at "Fostering a Dynamic Global Recovery," A Symposium sponsored by the Federal Reserve Bank of Kansas City, Jackson Hole, Wyoming (Aug. 25). 